Portland State University

PDXScholar

Winter 1-8-2015

\title{
Sensible Air to Air Heat Recovery Strategies in a Passive House
}

Santiago Martin Rodriguez-Anderson

Portland State University

Follow this and additional works at: https://pdxscholar.library.pdx.edu/open_access_etds

Part of the Energy Systems Commons, Environmental Design Commons, and the Sustainability Commons

Let us know how access to this document benefits you.

\section{Recommended Citation}

Rodriguez-Anderson, Santiago Martin, "Sensible Air to Air Heat Recovery Strategies in a Passive House" (2015). Dissertations and Theses. Paper 2123.

https://doi.org/10.15760/etd.2121

This Thesis is brought to you for free and open access. It has been accepted for inclusion in Dissertations and Theses by an authorized administrator of PDXScholar. Please contact us if we can make this document more accessible: pdxscholar@pdx.edu. 
Sensible Air to Air Heat Recovery Strategies in a Passive House

by

Santiago Martin Rodriguez-Anderson

A thesis submitted in partial fulfillment of the

requirements for the degree of

\author{
Master of Science \\ in \\ Mechanical Engineering
}

Thesis Committee:

David Sailor, Chair

Huafen $\mathrm{Hu}$

Graig Spolek

Portland State University

2014 
(C2014 Santiago Martin Rodriguez-Anderson 


\begin{abstract}
Due to rising energy costs and concerns about global climate change, high performance buildings are more in demand than ever before. With roughly $20 \%$ of the total energy consumption in the United States being devoted to residential use, this sector represents a significant opportunity for future savings. There are many guidelines and standards for reducing building energy consumption. One of the most stringent is the Passive House Standard. The standard requires that that air infiltration is less than or equal to 0.6 air changes per hour at a 50 Pascal pressure difference $\left(\mathrm{ACH}_{50}\right)$, annual heating energy is less than or equal to $15 \mathrm{kWh} / \mathrm{m}^{2}$, and total annual source energy is less than or equal to $120 \mathrm{kWh} / \mathrm{m}^{2}$. For comparison, the typical West coast US residence has an $\mathrm{ACH}_{50}$ of 5 and annually uses more than $174 \mathrm{kWh} / \mathrm{m}^{2}$ of source energy according to the 2009 Residential Energy Consumption Survey. With these challenging requirements, successful implementation of the Passive House Standard requires effective strategies to substantially reduce energy consumption for all end uses.

Heating and cooling loads are low by necessity in a Passive House. As such this makes end uses like water heating a much larger fraction of total energy use than they would be in a typical building. When air to water heat pumps are employed the energy consumption by water heating is lowered significantly. By employing innovative heat recovery strategies the energy consumption for water heating and HVAC can be reduced even further. This
\end{abstract}


study uses energy modeling and project cost analysis to evaluate three innovative control strategies. Results for a Passive House in Portland Oregon show a savings of about $\$ 70$ annually with a payback period of 10 years. The same Passive House in Fairbanks Alaska with a different strategy would save $\$ 150$ annually with a payback period of 5 years. 


\section{Dedication}

I dedicate this thesis to my wife Krista who always encouraged me to think big and always made me laugh when times got tough. I also owe thanks to La Familia Rodriguez and the rest of my friends and family who supported me through the trials and tribulations of higher education. 


\section{Acknowledgments}

Foremost, I would like to express my gratitude to my advisor and committee chair, David Sailor, for his steadfast support and guidance. I would also like to thank my committee members, Huafen Hu and Graig Spolek, for their support and feedback.

I would like to thank Ella Wong, Randy Hayslip for letting me troubleshoot equipment in their house and spend time observing what it is like living in the house of the future.

Special thanks to Jeff Lauck for helping debug my EnergyPlus Programs, and Natalie Sherwood for listening to my colorful observations on programming.

The Trekhaus project would not have been possible without current and former students and staff of the Green Building Research Laboratory, especially Jeff Lauck, Christophe Parroco, Daeho Kang, Pamela Wallace, Stephanie Jacobsen, and Steve Gross for their assistance with instrument installation, energy modeling, and data analysis. 


\section{Contents}

Abstract

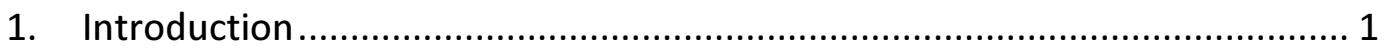

1.1 Motivation and background ........................................................ 1

1.1.1 Inspiration for This Study ...................................................... 3

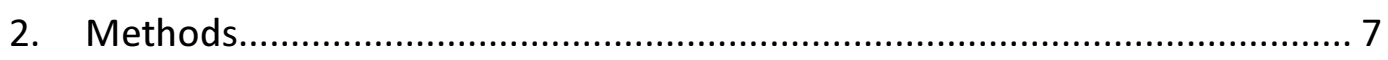

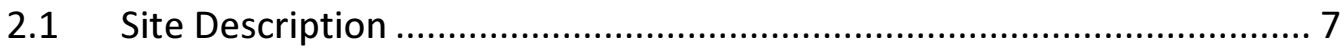

2.1.1 Location and Climate .......................................................... 7

2.1.2 Construction Details and Occupancy ........................................ 9

2.1.3 Mechanical Equipment Description........................................ 12

$2.2 \quad$ EnergyPlus Model Description ...................................................... 13

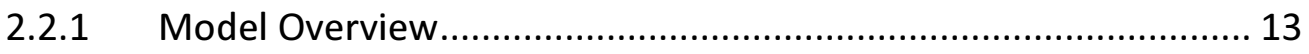

2.2.2 Key Features of the Simplified Model........................................ 15

2.2.3 Major Components, Assumptions, and Limitations ..................... 21

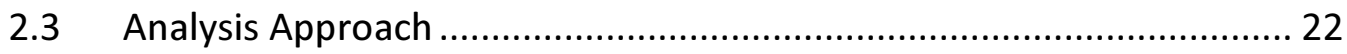

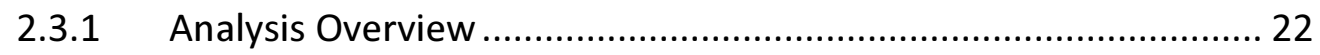

2.3.2 Heat Recovery Experimentation with Energy Model .................... 22

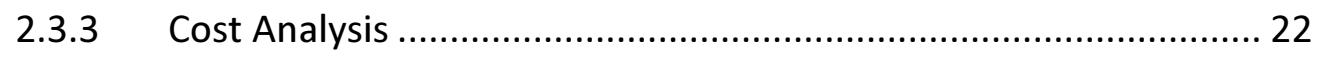

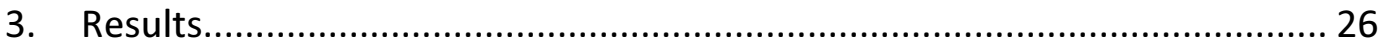

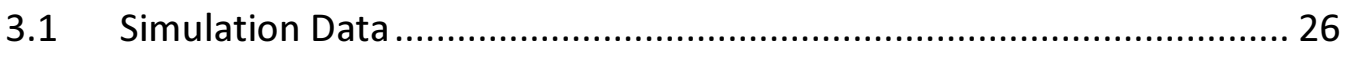

3.1.1 Baseline Case Simulation Results................................................. 26

3.1.2 End Use Energy Savings for Portland Oregon........................... 27

3.1.3 Total Energy Savings for all Simulated Cities .............................. 29

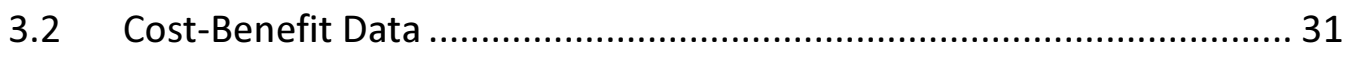




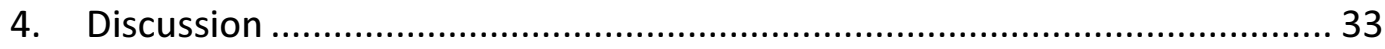

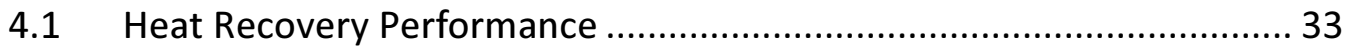

4.1.1 Analysis of Energy Data.............................................................. 33

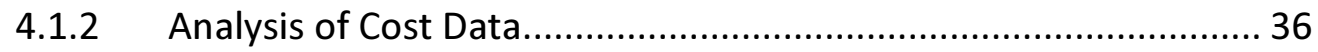

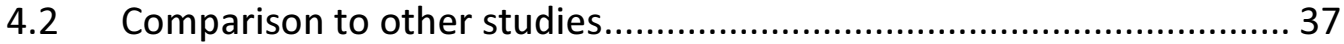

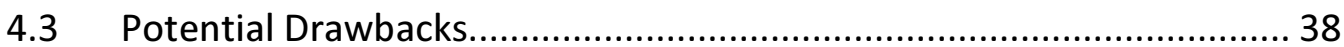

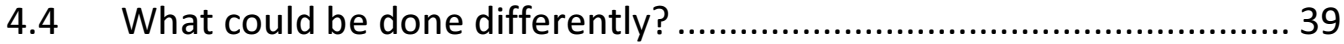

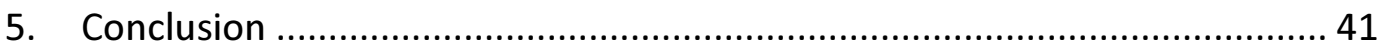

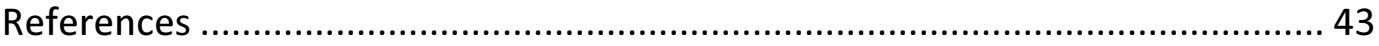

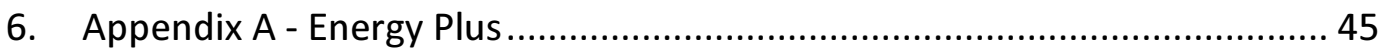

7. Appendix B - Additional Data Figures ....................................................... 53

8. Appendix C - Contents of Supplemental Data Files...........................................58 


\section{List of Tables}

Table 2-1 Summary data of simulation climate data.................................9

Table 2-2 Envelope construction summary for simplified Passive House

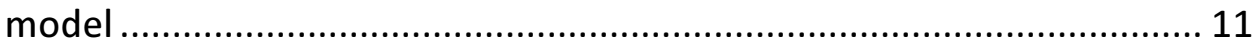

Table 2-3 Glazing summary for simplified Passive House model ............ 12

Table 2-4 Electric utility billing rates for chosen simulation cities .......... 24

Table 2-5 Summary of cost analysis metrics........................................ 24

Table 3-1 Cost-benefit results for Portland Oregon ............................ 32

Table 3-2 Cost-Benefit results for Fairbanks Alaska ............................. 32

Table 3-3 Cost-Benefit data for Phoenix Arizona .................................. 32 


\section{List of Figures}

Figure 1-1. An overview of energy consumption in the United States in 2010.

Figure 1-2 NREL evaluation of COP for the heat pump water heater used in the Trekhaus study. 15

Figure 1-3 Trekhaus heat recovery ventilator stream temperature. 6

Figure 1-4 Water heating energy profiles for Trekhaus ......................... 6

Figure 2-1 Location of Trekhaus ................................................... 7

Figure 2-2 Map of all simulation climates........................................ 8

Figure 2-3 Trekhaus, a passive house duplex home ............................. 9

Figure 2-4 Open studio model of a Passive House created in Sketchup .. 10

Figure 2-5 Base line HVAC diagram ................................................ 17

Figure 2-6 Case A: Heat recovery of HRV exhaust diagram.................... 18

Figure 2-7 Case B: Heat recovery of cold HPWH compressor exhaust..... 19

Figure 2-8 Case C: Combined strategies of Case A and Case B................ 20

Figure 3-1 Baseline Case energy consumption for Passive House model in

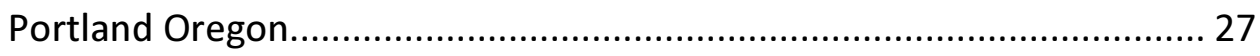

Figure 3-2 Energy savings compared to the Baseline Case for fans in

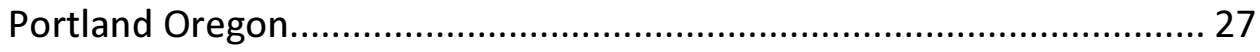

Figure 3-3 Energy savings compared to the Baseline Case for cooling in 
Portland Oregon...

Figure 3-4 Energy savings compared to the Baseline Case for heat

recovery in Portland Oregon............................................................ 28

Figure 3-5 Energy savings compared to the Baseline Case for hot water in

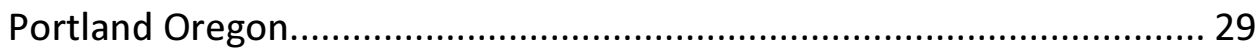

Figure 3-6 Total Energy savings from Baseline Case in Portland Oregon..30

Figure 3-7 Total energy savings compared to Baseline Case in Fairbanks

Alaska

Figure 38 Total energy savings compared to Baseline Case in Phoenix

Arizona. 


\section{Introduction}

\subsection{Motivation and background}

The United States accounted for $19 \%$ of the world's primary energy consumption. Roughly twenty two percent of that primary energy consumption was used in residential buildings [1]. The combined statistic is that residences in the United States consume $4.2 \%$ of global primary energy produced. This means that U.S. homes consume nearly one twentieth of the primary energy produced worldwide.

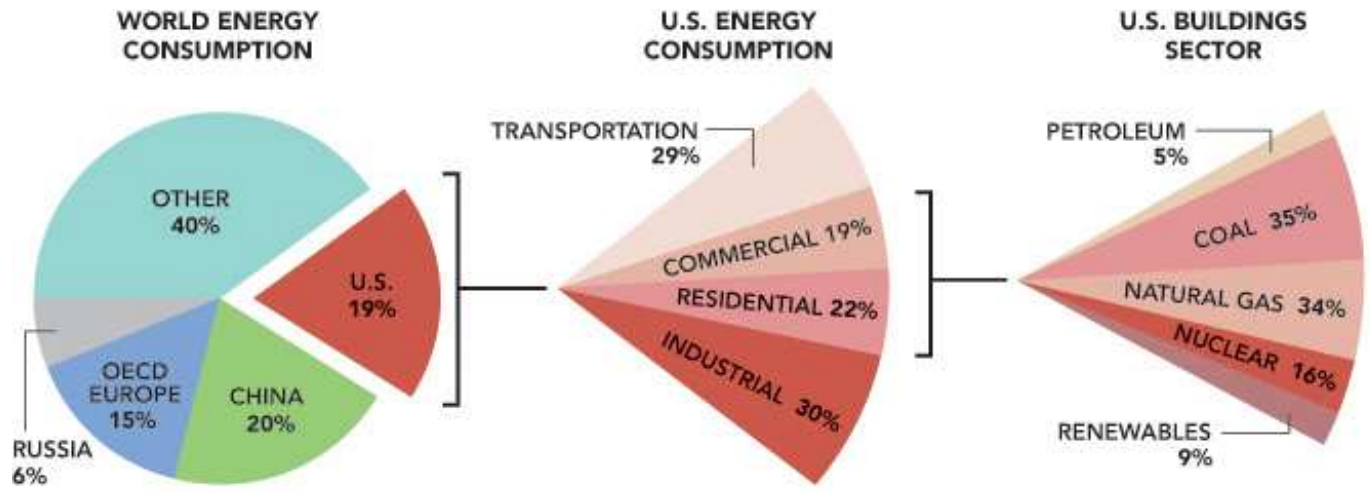

Figure 1-1. An overview of energy consumption in the United States in 2010. Commercial and residential buildings in the U.S. account for $41 \%$ of the country's total source energy consumption. [1].

Rising energy prices and strong indicators of global climate change have begun to shift policy toward high efficiency in as many aspects of American life as possible. The Passive House standard is fast becoming a leading efficiency standard for residential buildings. The Passive House Standard is widely used 
throughout Europe and is becoming more common in the United States.

Originally developed in Germany, the Passive house Standard requires not only consideration of total site energy consumption, but also source energy use. Source energy and site energy consumption differ in that site energy only accounts for end use totals, while source energy accounts for losses in production and transmission. A building that produces electricity on site would have a lower source energy consumption than a similar building that gets its electricity from the grid [2].

The Passive House Standard requires that a building use less than or equal to $120 \mathrm{kWh} / \mathrm{m}^{2}$ per year of total source energy, and less than or equal to $15 \mathrm{kWh} / \mathrm{m}^{2}$ of heating and cooling energy. In addition the standard requires that infiltration rates be no more than 0.6 air changes per hour at a 50 Pascal [3]. This ends up being roughly $10 \%$ of a typical home's energy consumption and $10 \%$ of typical infiltration rates [4]. The strict requirements on infiltration necessitate the use of airtight envelopes and heat recovery ventilators to provide sufficient fresh air to building occupants without sacrificing occupant comfort. In addition to high efficiency ventilators, efficient heating and cooling is also necessary to achieve the strict $15 \mathrm{kWh} / \mathrm{m}^{2}$ requirement. Typically a heat pump of some kind will achieve this end. A variety of other energy efficient appliances are often used. If energy consumption for heating and cooling is reduced to about a tenth of the allowable energy use intensity, then hot water heating will become the largest end use. Tankless water heaters and heat pump water heaters are 
popular choices to help reduce consumption from this end-use.

Heat pumps use a refrigeration cycle to either reject heat from a space or to add heat to it. If a heat pump is rejecting heat from a space, its efficiency is improved as the environment around the condenser gets colder. This is because a greater temperature difference increases the rate of heat rejection with the environment. This is similar to the case where heat is being added to an environment with a heat pump. A greater temperature difference between the heat reservoir and the evaporator increases the rate of heat addition to the environment. These basic principles of heat pumps mean that any time that an environment can be made more favorable for an evaporator or condenser, the heat pump will require less energy to operate. These more favorable conditions could be achieved with strategic recovery of waste heat. These benefits would vary depending on the typical operating environment. To observe the full range of operating possibilities one would need to examine operation across a range of climate conditions.

\subsubsection{Inspiration for This Study}

Trekhaus is a Passive House that has been a part of a variety of studies by the Green Building Research Lab since it was first occupied by the owners in 2012 [4]. This building is a Passive House duplex located in Portland Oregon. Key 
features include walls with an R-value (SI) of 9.82 triple paned argon-filled windows, mini-split heat pump, heat recovery ventilator, and heat pump water heater [5]. Additionally, the Trekhaus includes Phase Change materials in the western unit in an attempt to improve thermal comfort. The Trekhaus occupants and researches noted that the heat pump water heater in their workshop put out cold air exhaust whenever it operated. During the summer, the occupants would leave the workshop door open to cool the house with exhaust air. It became a matter of curiosity among the researchers as to what level of benefit this afforded the occupants. On an intuitive level it made sense to make use of the free cooling.

Further investigation led to the conclusion that measures to raise the operating air temperature of the heat pump water heater were desirable. NREL did a study on a group of five different heat pump water heaters to evaluate a variety of performance metrics [6]. One of those water heaters studied included the water heater used in Trekhaus. One important finding of that study was that the Coefficient of Performance (COP) of the hot water heaters was highly dependent upon the Wet Bulb (WB) temperature of the compressor air intake. The trend was that a higher wet bulb temperature meant a higher COP for the water heater (see Figure 2-1). There is a positive correlation with wet bulb temperature and dry bulb temperature. A higher dry bulb temperature means a higher enthalpy of air entering the compressor intake. 


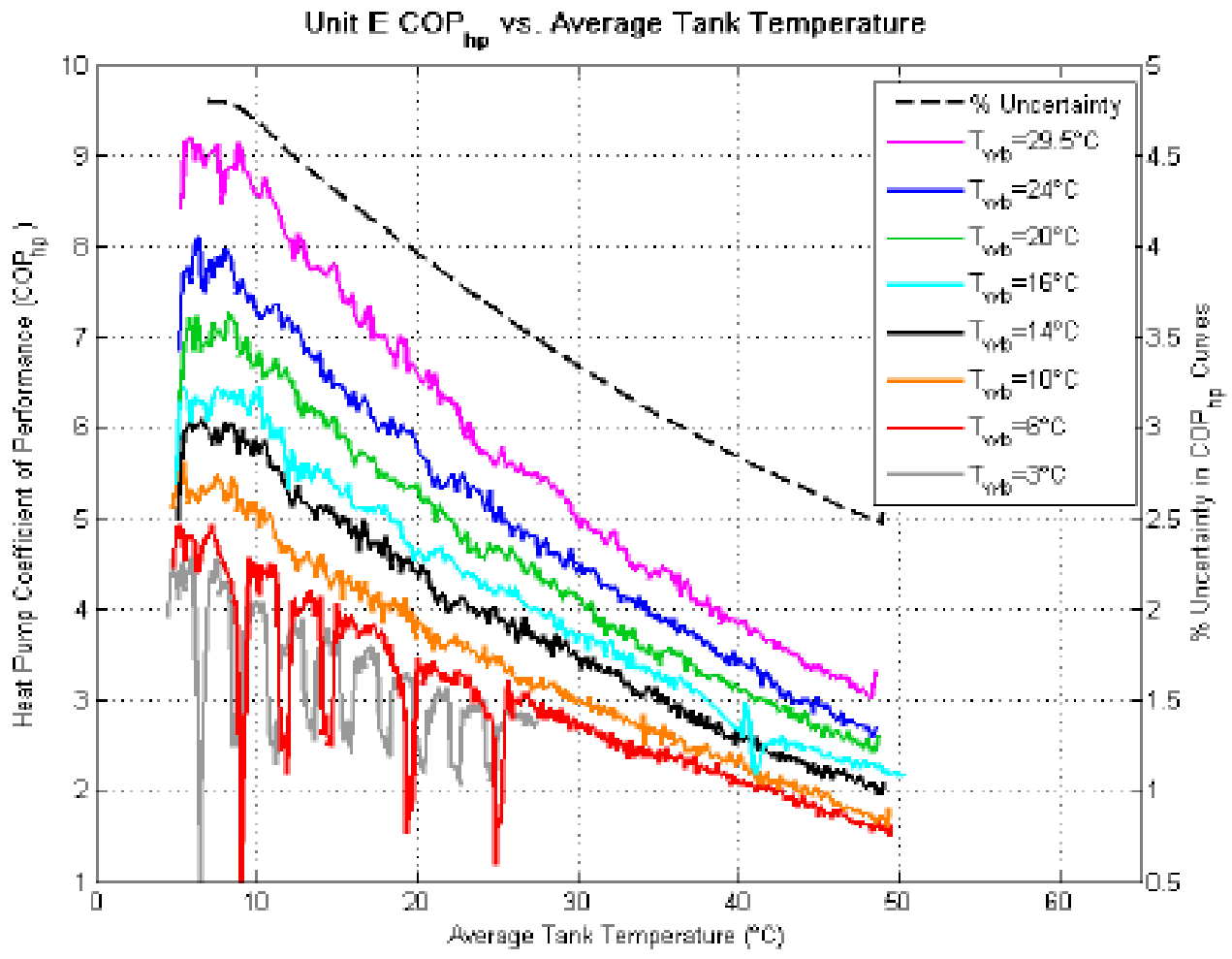

Figure 1-2 NREL evaluation of COP for the heat pump water heater used in the Trekhaus study. (From: Laboratory Performance Evaluation of Residential Integrated Heat Pump Water Heaters)[6]

As part of a study of the heat recovery ventilator efficiency in the Trekhaus, a large quantity of data for typical air temperatures at each of the ducts leading into and out of the ventilator was recorded and analyzed. The general observation was that the exhaust air was warmer at night than the outdoor air because of the ventilator operating in economizer mode (see Figure 1-3). This continued into the late morning while hot water was being heated (see Figure 1-4) [5]. It seemed likely that there could be some energy savings by using that exhaust air to help heat the intake air for the hot water heater. This would 
be especially true in the winter months, as the occupants noted that it got colder in the workshop than it did outside.

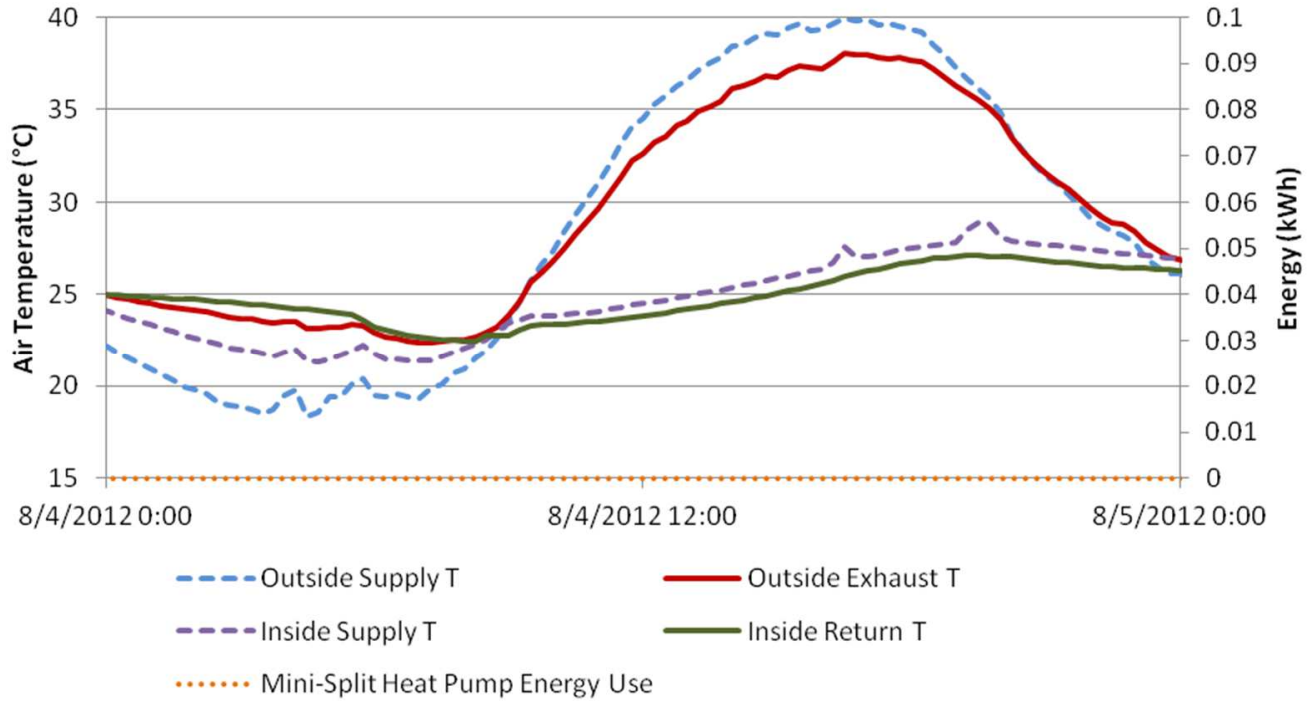

Figure 1-3 Trekhaus heat recovery ventilator stream temperatures [5]

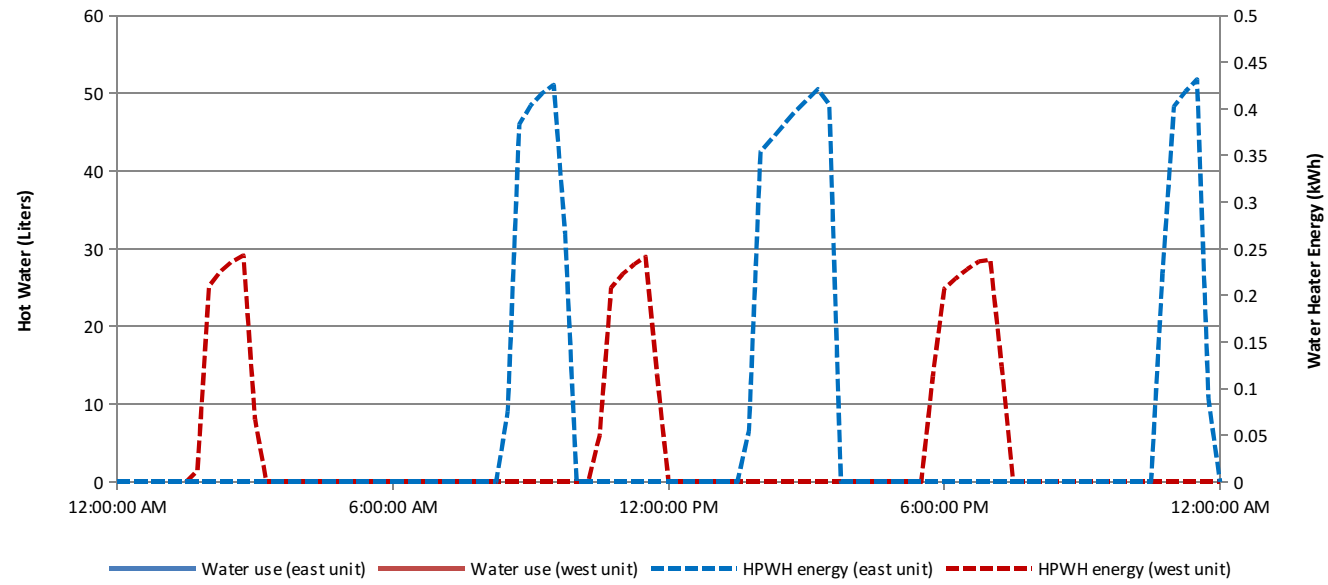

Figure 1-4 Water heating energy profiles for Trekhaus [5] 


\section{Methods}

This analysis uses collected data on the construction and operation of a house used in a field study in Portland Oregon. This data is incorporated into an energy model which then provides energy consumption data. The energy consumption data is used for cost analysis.

\subsection{Site Description}

The sites for the simulation study include the original field study location in Portland Oregon as well as two additional locations with different climates.

\subsubsection{Location and Climate}

The model used in this study is based on the Trekhaus passive house.

Trekhaus is a privately-owned three-bedroom duplex in Portland Oregon. The

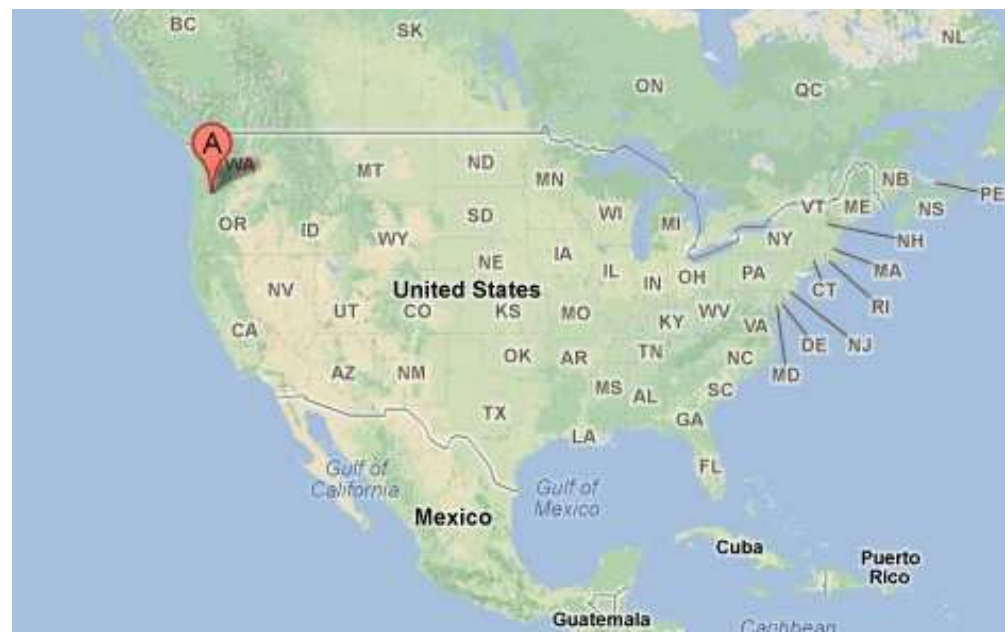

Figure 2-1 Location of Trekhaus (https://maps.google.com)

general location in the United States is shown in Figure 2-1. Trekhaus was designed to meet the Passive House standard in ASHRAE Climate Zone 4C, a mixed marine climate with 2346 heating degree days and 235 cooling degree 
days $\left(18.3^{\circ} \mathrm{C}\right.$ base) [7]. The same building model is also evaluated in Pheonix Arizona, and Fairbanks Alaska to provide a cold climate and a hot climate to compare equipment operation conditions. The general locations for the model are shown in Figure 2-2. There were no changes to the model for different climate conditions. It should be noted that there would be construction and design differences to be able to meet the passive house standard in different climates. Each of these climates would present different demands on the building. A building in Fairbanks would use substantially more energy for zone heating or water heating than a building in Portland. The same building in Pheonix would have much higher demands for cooling than its twin in Portland.

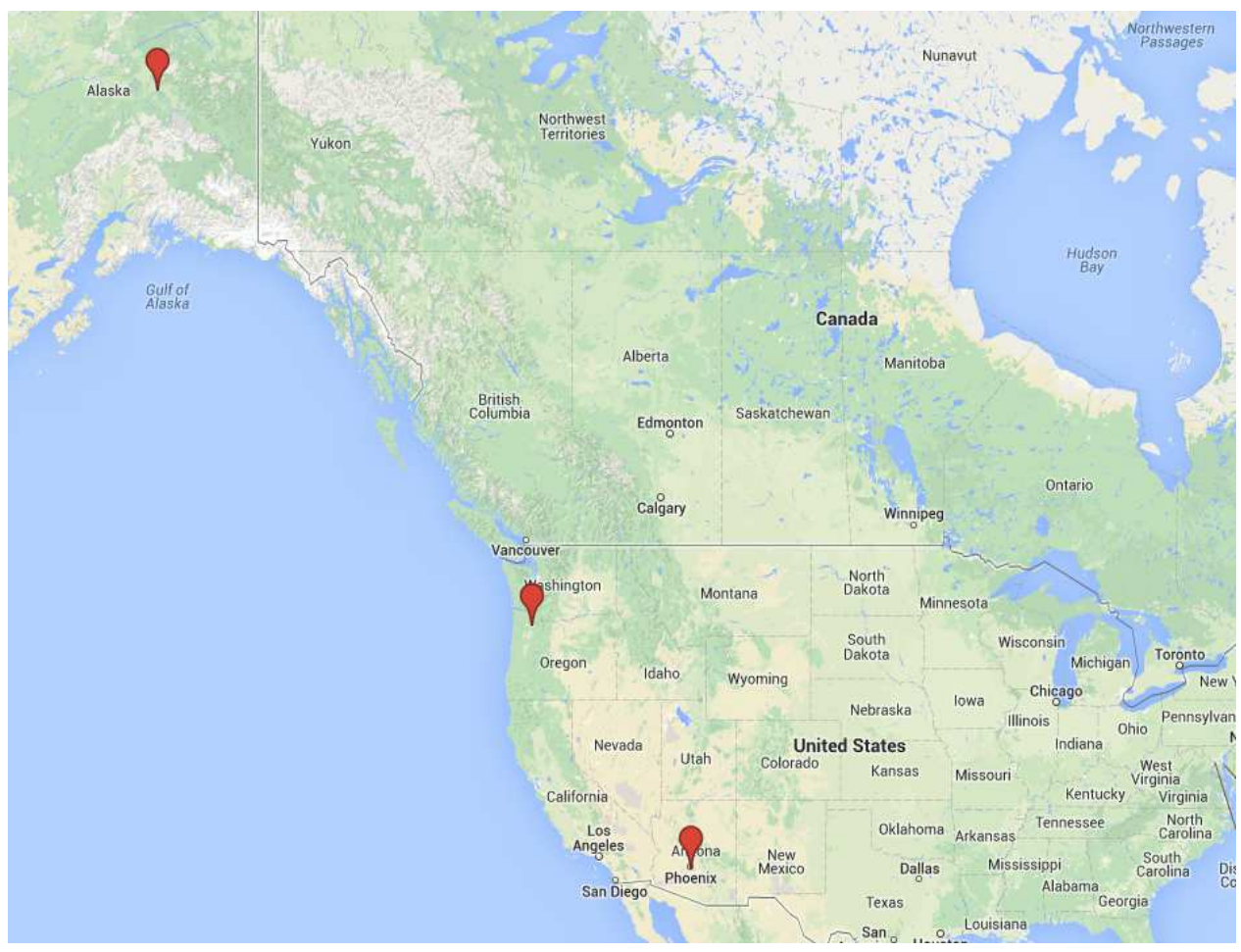

Figure 2-2 Map of all simulation climates (https://maps.google.com) 
Table 2-1 Summary data of simulation climate data

\begin{tabular}{rlll} 
Location & $\begin{array}{l}\text { Heating Degree } \\
\text { Days }\end{array}$ & $\begin{array}{l}\text { Cooling Degree } \\
\text { Days }\end{array}$ & $\begin{array}{l}1 \% \\
\text { Dehumidification } \\
\text { HR } \\
\text { (grains/kgda) }\end{array}$ \\
\hline \begin{tabular}{r|rr} 
Portland OR at PDX AP \\
Pheonix AZ at Sky
\end{tabular} & 2346 & 235 & 11.0 \\
Harbor AP & 523 & 2532 & 16.3 \\
Fairbanks AL AP & 7516 & 39 & 9.8
\end{tabular}

\subsubsection{Construction Details and Occupancy}

Trekhaus is a two story duplex from which many model elements were

selected. Some Items of particular importance are the high window to wall ratio

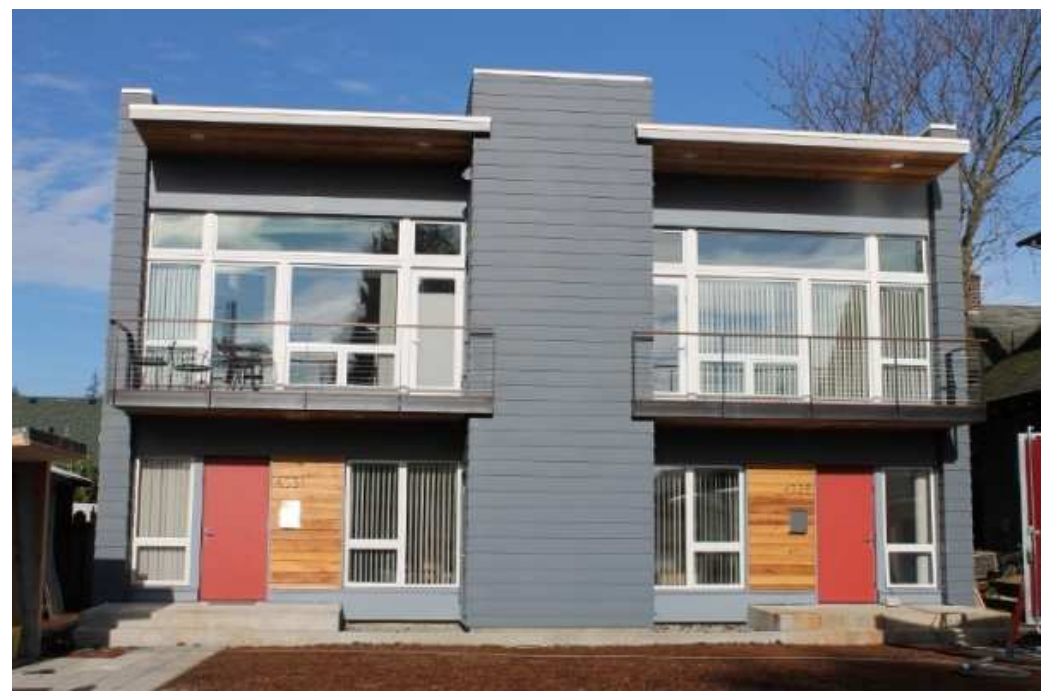

Figure 2-3 Trekhaus, a passive house duplex home, is divided into two mirror-image apartments with a party wall on the north-south axis.

on the soutnern walı, totaı tıoor area, intıtratıon rates, ventılatıon rates, and

envelope construction. The model in this simulation study is a single floor and a

stand-alone structure. The building has a conditioned floor area of $148.6 \mathrm{~m}^{2}$, and 
an unconditioned work shop with floor area of $9.3 \mathrm{~m}^{2}$. Although the workshop is unconditioned, its walls are still built up like the exterior to separate it both from the conditioned zone and the outside conditions. The model has only one floor to more effectively treat the building as a single conditioned zone. Lighting density was determined from the electrical equipment loads that were tallied from Trekhaus surveys and provided they overall equipment load for this model. The envelope for the model is a simplified version of what was used in Trekhaus. The exterior wall construction layers from outside to inside are wood siding, $100 \mathrm{~mm}$ foil faced polyisocyanurate insulation, $12 \mathrm{~mm}$ plywood sheathing, 184 $\mathrm{mm}$ blown-in cellulose insulation, and $16 \mathrm{~mm}$ gypsum board. From outside to inside, roof construction consists of a single-ply membrane, $178 \mathrm{~mm}$

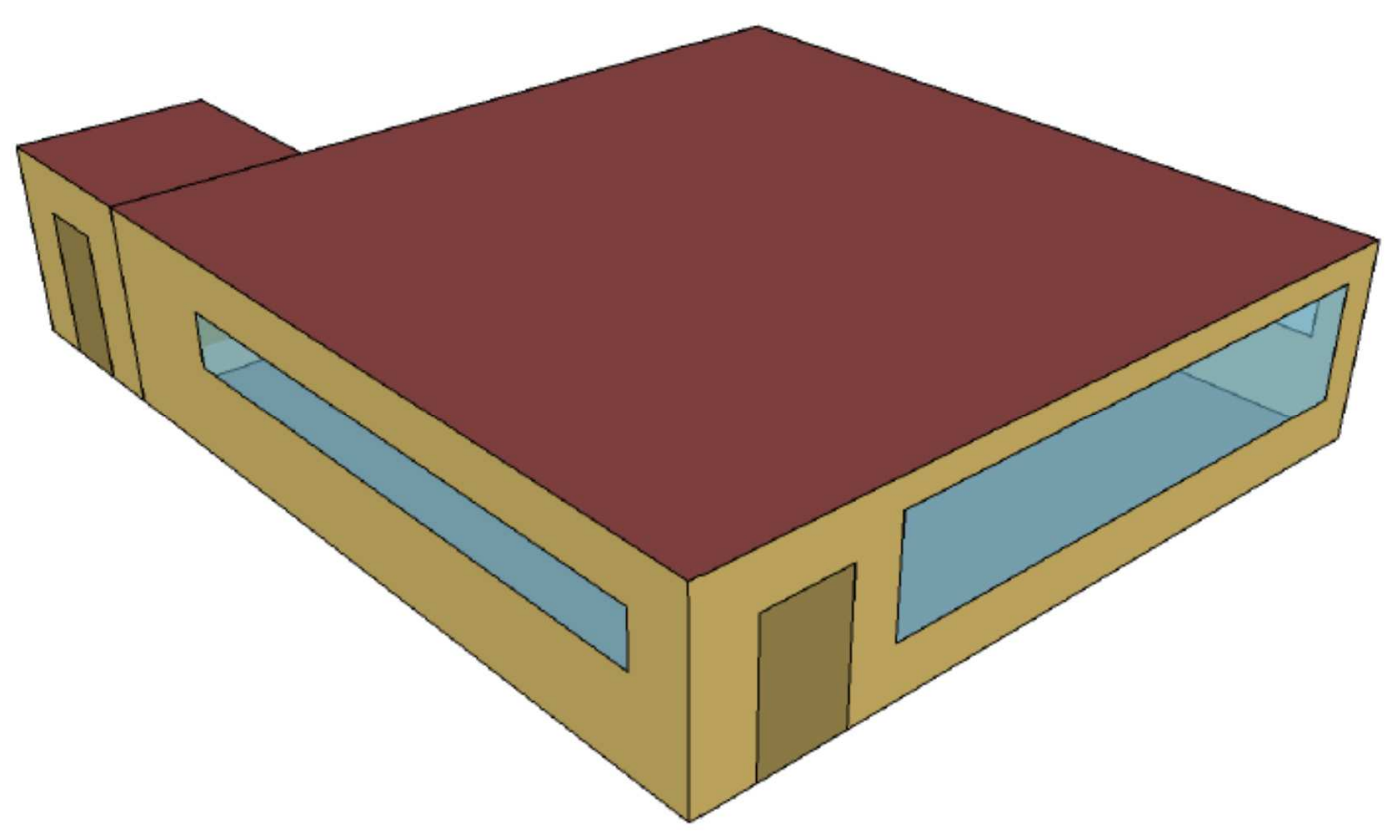

Figure 2-4 Open studio model of a Passive House created in Sketchup

polyisocyanurate insulation, $19 \mathrm{~mm}$ plywood decking, $300 \mathrm{~mm}$ blown-in cellulose 
insulation, and $16 \mathrm{~mm}$ gypsum board. The floor is a $100 \mathrm{~mm}$ thick concrete slab insulated with $170 \mathrm{~mm}$ of expanded perlite and $100 \mathrm{~mm}$ of expanded polystyrene. The data for this construction is summarized in Table 2-2.

The windows in the model are all fixed frame with three layers of glazing and a $90 \%$ argon/10\% air mixture in between the panes. Low-e coatings are also used to affect the Solar Heat Gain Coefficient (SHGC) of the windows. The South facing windows have coatings on surfaces three and five, while all other windows have the coatings on surfaces two and five (counting from inside to outside). The details of the glazing are summarized in Table 2-4.

Table 2-2 Envelope construction summary for simplified Passive House model

\begin{tabular}{|c|c|c|c|c|c|}
\hline Construction & Material & $\begin{array}{l}\text { Thickness } \\
\text { (m) }\end{array}$ & $\begin{array}{c}\text { Thermal } \\
\text { Conductivity } \\
(W / m K)\end{array}$ & $\begin{array}{c}R- \\
\text { Value } \\
\left(m^{2}\right. \\
k / W)\end{array}$ & $\begin{array}{c}\text { Total } \\
\text { Assembly } \\
\text { R-Value } \\
\left(\mathrm{m}^{2} \mathrm{k} / \mathrm{W}\right)\end{array}$ \\
\hline \multirow{3}{*}{$\begin{array}{r}\text { Foundation } \\
\text { Slab }\end{array}$} & Expanded Perlite & 0.171 & 0.054 & 3.156 & \multirow{3}{*}{6.11} \\
\hline & $\begin{array}{l}\text { Extruded } \\
\text { Polystyrene }\end{array}$ & 0.102 & 0.035 & 2.910 & \\
\hline & Concrete & 0.102 & 2.060 & 0.049 & \\
\hline \multirow{6}{*}{$\begin{array}{r}\text { Exterior } \\
\text { Wall }\end{array}$} & Siding & 0.019 & 0.103 & 0.185 & \multirow[t]{6}{*}{9.82} \\
\hline & Air Gap & - & - & 0.150 & \\
\hline & $\begin{array}{l}\text { Polyisocyanurate } \\
\text { Insulation }\end{array}$ & 0.102 & 0.021 & 4.826 & \\
\hline & $\begin{array}{l}\text { Plywood } \\
\text { Sheathing }\end{array}$ & 0.013 & 0.098 & 0.130 & \\
\hline & $\begin{array}{l}\text { Blown-In Cellulose } \\
\text { Insulation }\end{array}$ & 0.184 & .042 & 4.431 & \\
\hline & Gypsum Board & 0.016 & .159 & 0.100 & \\
\hline \multirow[t]{5}{*}{ Roof } & $\begin{array}{l}\text { Single-Ply } \\
\text { Membrane }\end{array}$ & - & - & - & \multirow[t]{5}{*}{15.97} \\
\hline & $\begin{array}{l}\text { Polyisocyanurate } \\
\text { Insulation }\end{array}$ & 0.178 & 0.021 & 8.445 & \\
\hline & Plywood Decking & 0.016 & 0.098 & 0.165 & \\
\hline & $\begin{array}{l}\text { Blown-In Cellulose } \\
\text { Insulation }\end{array}$ & 0.302 & 0.042 & 7.258 & \\
\hline & Gypsum Board & 0.016 & 0.159 & 0.100 & \\
\hline
\end{tabular}


Table 2-3 Glazing summary for simplified Passive House model

\begin{tabular}{|c|c|c|c|c|c|c|c|}
\hline \multirow[t]{2}{*}{ Façade } & \multirow{2}{*}{$\begin{array}{c}\text { Window } \\
\text { Type }\end{array}$} & \multirow{2}{*}{$\begin{array}{c}\text { Low-e } \\
\text { Surfaces }\end{array}$} & \multicolumn{3}{|c|}{ Center of Glass } & \multicolumn{2}{|c|}{ Total Window } \\
\hline & & & $\begin{array}{l}\text { Visible } \\
\text { Transmittance }\end{array}$ & SHGC & $\begin{array}{l}\text { U-factor } \\
\left(\mathrm{W} / \mathrm{m}^{2} \mathrm{~K}\right)\end{array}$ & SHGC & $\begin{array}{l}\text { U-factor } \\
\left(\mathrm{W} / \mathrm{m}^{2} \mathrm{~K}\right)\end{array}$ \\
\hline South & Fixed & 3,5 & 0.63 & 0.59 & 0.88 & 0.51 & 0.97 \\
\hline $\begin{array}{c}\text { North, } \\
\text { East, } \\
\text { West }\end{array}$ & Fixed & 2,5 & 0.57 & 0.36 & 0.71 & 0.31 & 0.81 \\
\hline
\end{tabular}

\subsubsection{Mechanical Equipment Description}

The passive house standard sets high standards for primary energy consumption as a whole, but for HVAC needs in particular. Trekhaus meets its heating and cooling needs with a Mitsubishi Mr. Slim mini-split heat pump, consisting of an SUZ-KA09NA outdoor unit coupled to an SEZ-KD09NA indoor unit. This system has rated heating and cooling capacities of $3.2 \mathrm{~kW}$ and $2.4 \mathrm{~kW}$, respectively. The specifications of this heat pump were chosen for the simplified Passive House model. Due to the low infiltration rates in Passive Houses, dedicated mechanical ventilation systems are needed to provide appropriate indoor air quality for occupants. The addition of heat recovery is a common choice because it reduces the demand for heating and cooling by preconditioning air entering a space. Depending on the climate, either a flat plate heat exchanger or a heat wheel are used for heat recovery. A climate without high dehumidification demand is ideal for a flat plate heat exchanger 
like the one used in Trekhaus. The full air handling unit including the heat exchanger, supply, and exhaust fans is commonly referred to as a Heat Recovery ventilator (HRV). The simplified Passive House model uses an HRV with specification matching that of the Zehnder ComfoAir ${ }^{\mathrm{TM}} 350$ used in Trekhaus.

Domestic hot water is another major source of energy consumption. Trekhaus meets its hot water needs with an AirGenerate AirTap ${ }^{\text {TM }}$ ATI50 heat pump water heater (HPWH) with a storage capacity of $189 \mathrm{~L}$. The water heater in Trekhaus is located in the unconditioned workshop. This particular HPWH has the compressor and evaporator fixed to the tank. As it is configured the workshop air serves as both the heat source and heat sink for HPWH refrigerant cycle. The heat pump is nominally rated at $2.75 \mathrm{~kW}$ with the primary and backup electric elements nominally rated at $4 \mathrm{~kW}$. This water heater can operate in three modes: heat pump only, electric element only, and hybrid mode.

\subsection{EnergyPlus Model Description}

The energy models described provide computational data to research without requiring extensive experimental setup.

\subsubsection{Model Overview}

The energy model used in this study was created using EnergyPlus, a whole building simulation developed by the U.S. Department of Energy [8]. Although EnergyPlus provides excellent flexibility and power in developing a model, creating even a simple building from scratch can be a tedious and error 
prone process. To this end NREL has developed a GUI energy modeling tool called Open Studio. Open Studio runs on the EnergyPlus engine and has plugins available for Sketchup. Sketchup and its Open Studio plugin were used to develop the basic floor plan and fenestration placement for the simplified Passive House model. The building geometry was then brought into the Open Studio environment where basic HVAC configurations, schedules, and setpoints were programmed in. This model was then exported to an EnergyPlus Input Design File (IDF). The IDF environment allows for objects to be imported from existing models.

The existing Trekhaus model was first developed by Christophe Parroco (a former staff member of the Green Building Research Laboratory) using the third-party GUI, DesignBuilder ${ }^{\mathrm{TM}}$, and then exported to the EnergyPlus Input Data File format. Further development of the HVAC systems, mainly the mini-split heat pump and HRV, was performed by Daeho Kang (a postdoctoral researcher in the Green Building Research Laboratory)[9]. Further validation and research on phase change material used in Trekhaus was done by Jeffery Lauck.

This model study will examine the effectiveness of employing additional sensible heat exchangers to make use of exhaust energy from both the heat pump water heater and the heat recovery ventilator. The particular EnergyPlus object that was added or modified was HeatExchanger:AirToAir:SensibleAndLatent. The simplified model in this study takes some HVAC, efficiency curves, and constructions from the Trekhaus model. 


\subsubsection{Key Features of the Simplified Model}

The Baseline Case of a simple passive house uses a heat recovery ventilator to bring in fresh outdoor air and exhaust stale air. When the enthalpy of the HRV return air is greater than that of the outdoor air, the bypass (economizer) mode is activated. Mechanical heating and cooling are provided solely by the heat pump. The heat pump water heater is in an unconditioned workshop adjacent to the house. The compressor inlet draws from the workshop air. The compressor also exhausts into the workshop. This Base Case is shown in Figure 2-5.

One alternate configuration is where the HRV exhaust air is passed to the exhaust side of an additional sensible heat exchanger before being sent outdoors. This air has a higher enthalpy than the outdoor air regardless of season or HRV operating mode because it contains some of the heat generated inside the house. Since the passive house would not be losing heat through infiltration, most of the sensible heat will be exhausted through the HRV. The supply side of the added heat exchanger takes in workshop air and preheats it before feeding into the HPWH compressor intake. The objective of this design is to improve the efficiency of the airside portion of the HPWH refrigeration cycle thereby reducing the HPWH energy consumption. Hereafter this configuration will be called Case A. The details of Case A can be seen in Figure 2-6.

Another configuration that is considered (Case B) sends exhaust from the 
HPWH compressor through the exhaust side of an added sensible heat exchanger. After passing through the heat exchanger, the outlet mixes with the workshop air. The supply side of the heat exchanger preconditions the room air before feeding to the MSHP intake. The desired effect is to reduce the need for cooling and heat recovery energy for the controlled zone. If the air being supplied to the interior space is preconditioned, then the bypass mode on the HRV can run for longer periods. Passive houses typically require more cooling than heating during shoulder seasons and summer so this can be a significant energy savings. In addition this will keep the workshop warmer and provide some improvement to the HPWH efficiency. Hereafter this configuration will be called as Case B. The details of Case B can be seen in Figure 2-7.

It is possible to combine Case A and Case B to try to reap different benefits at different times. In either case, HPWH energy consumption should be reduced. Even with this reduction, it could be beneficial to choose to precondition air entering the controlled zone, or to decouple the controlled zone from the workshop. This combined case would require two sensible heat exchangers and a series of dampers to control the flow path. The flow pathway is just as is described for Case A and Case B. Some additional dampers would be needed to ensure that only one of the cases is selected at a given time. This configuration will be called case $C$. The details of Case $C$ can be seen in Figure 2-8 


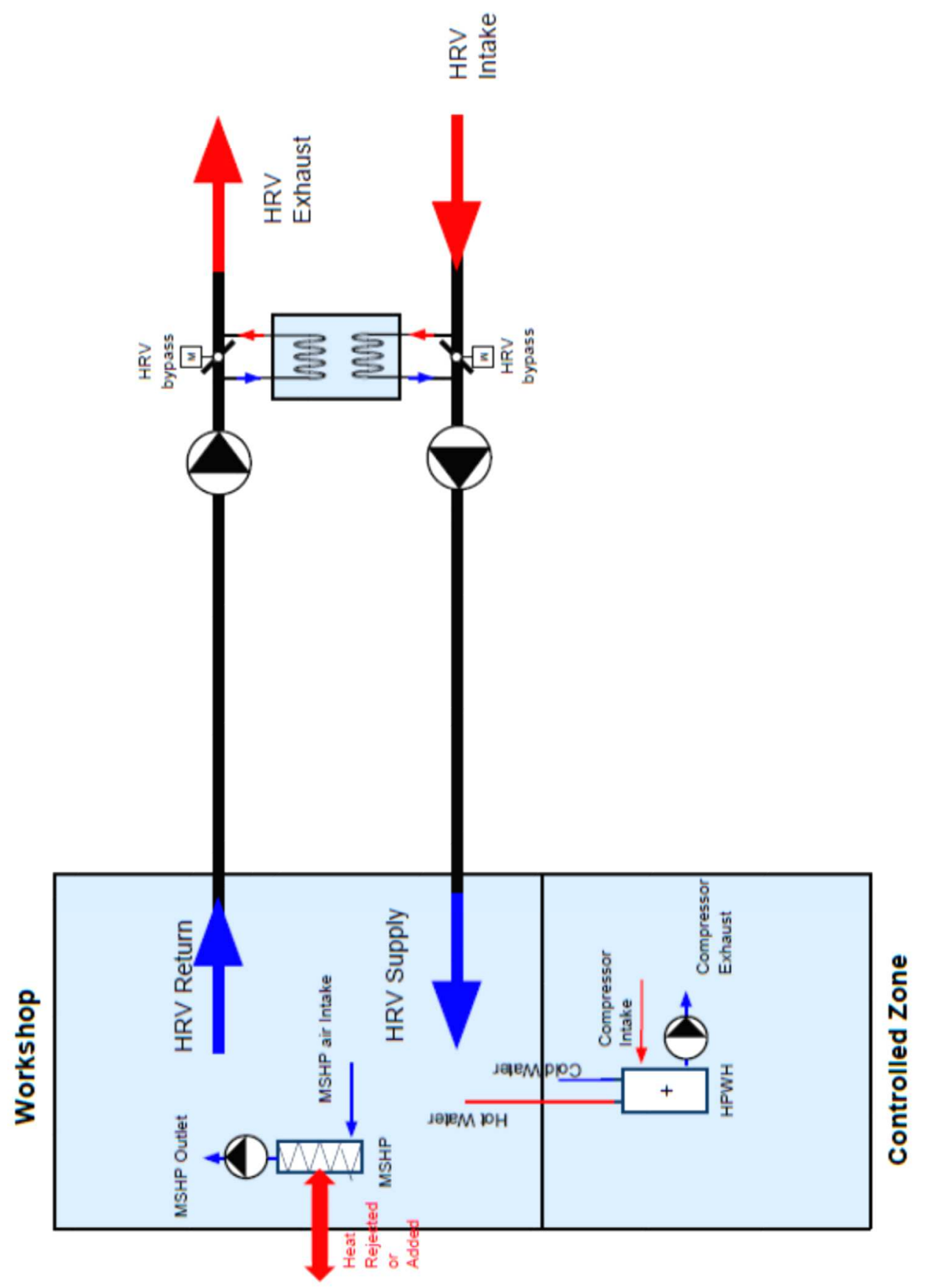

Figure 2-5 Base line HVAC diagram 


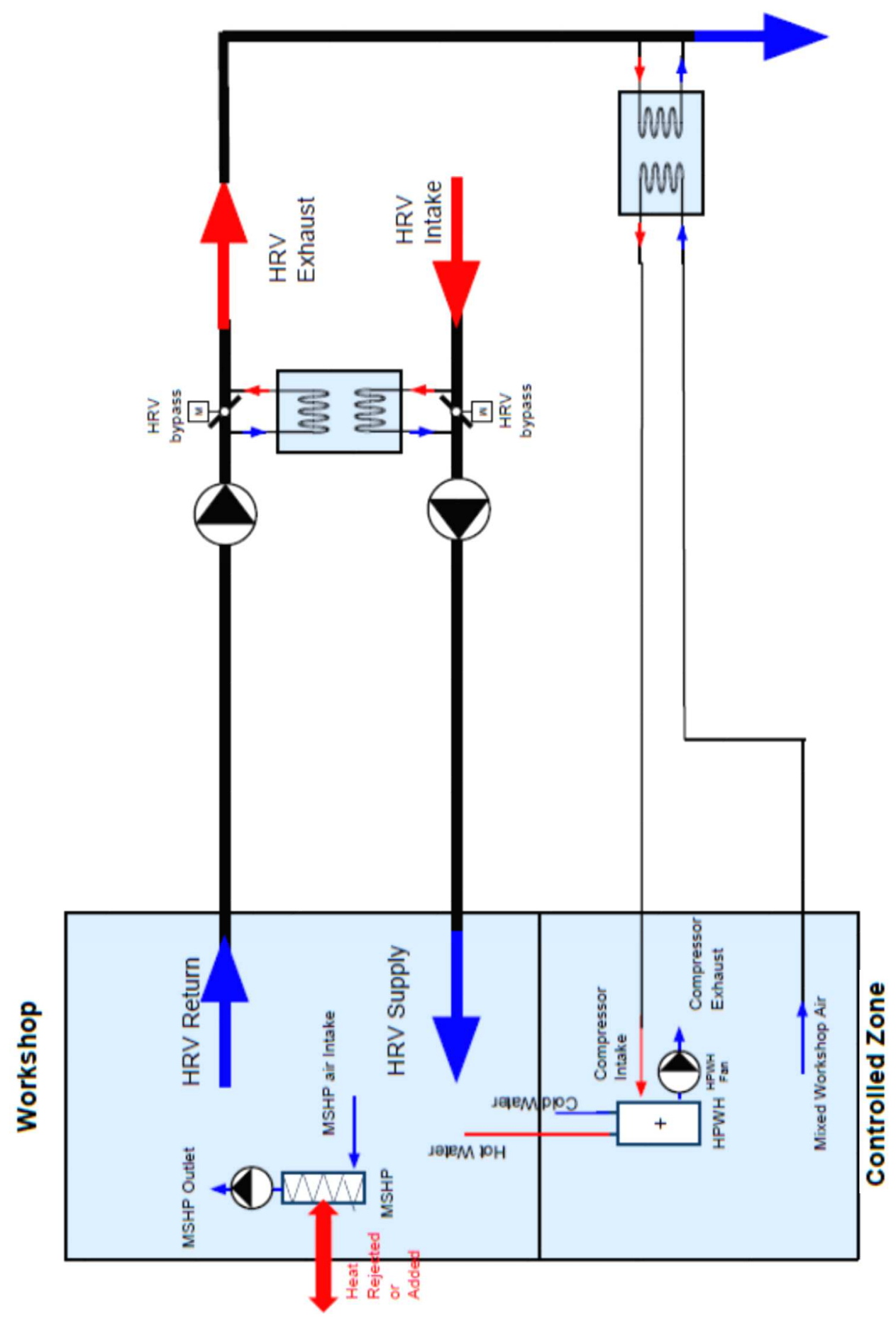

Figure 2-6 Case A: Heat recovery of HRV exhaust diagram 


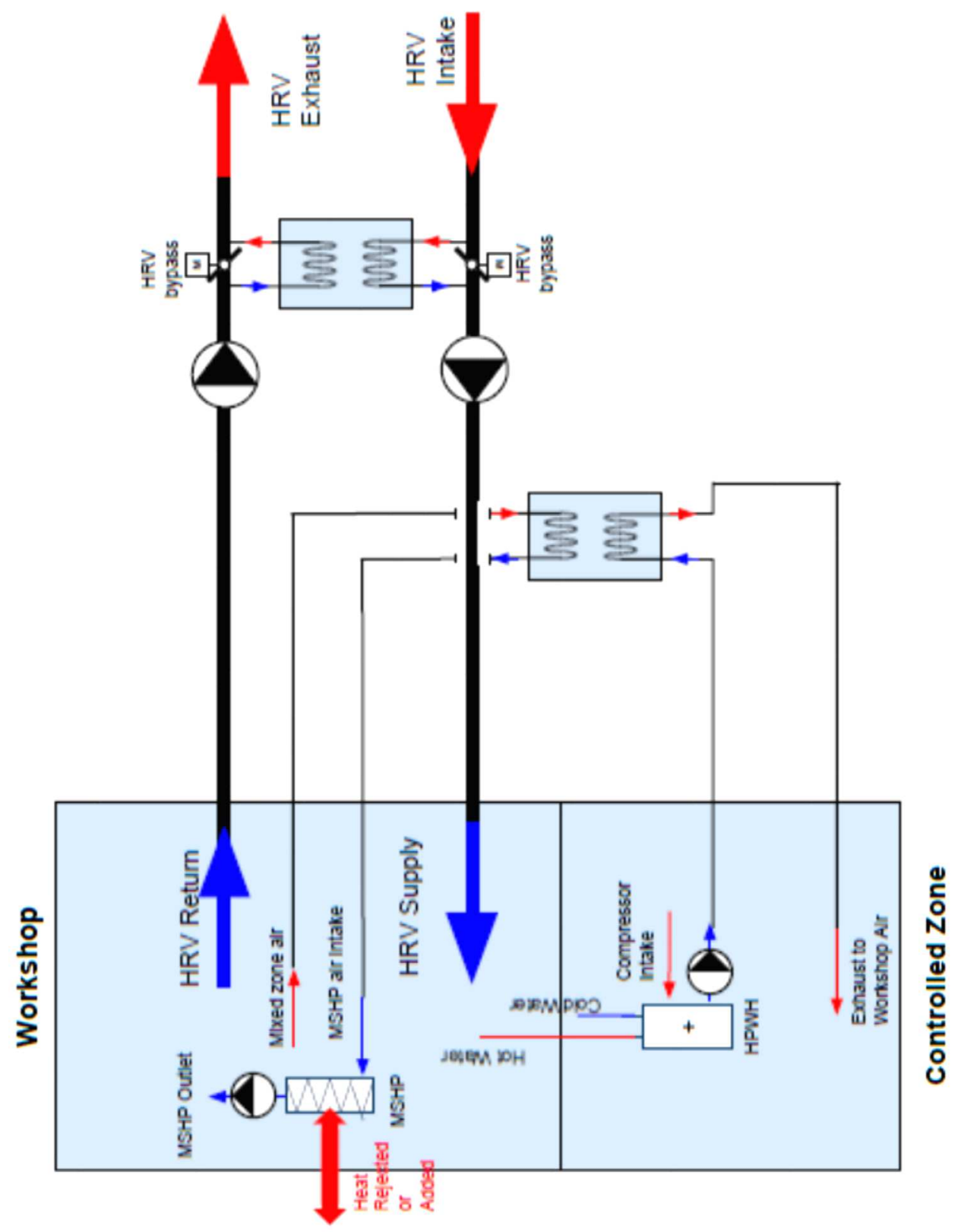

Figure 2-7 Case B: Heat recovery of cold HPWH compressor exhaust 


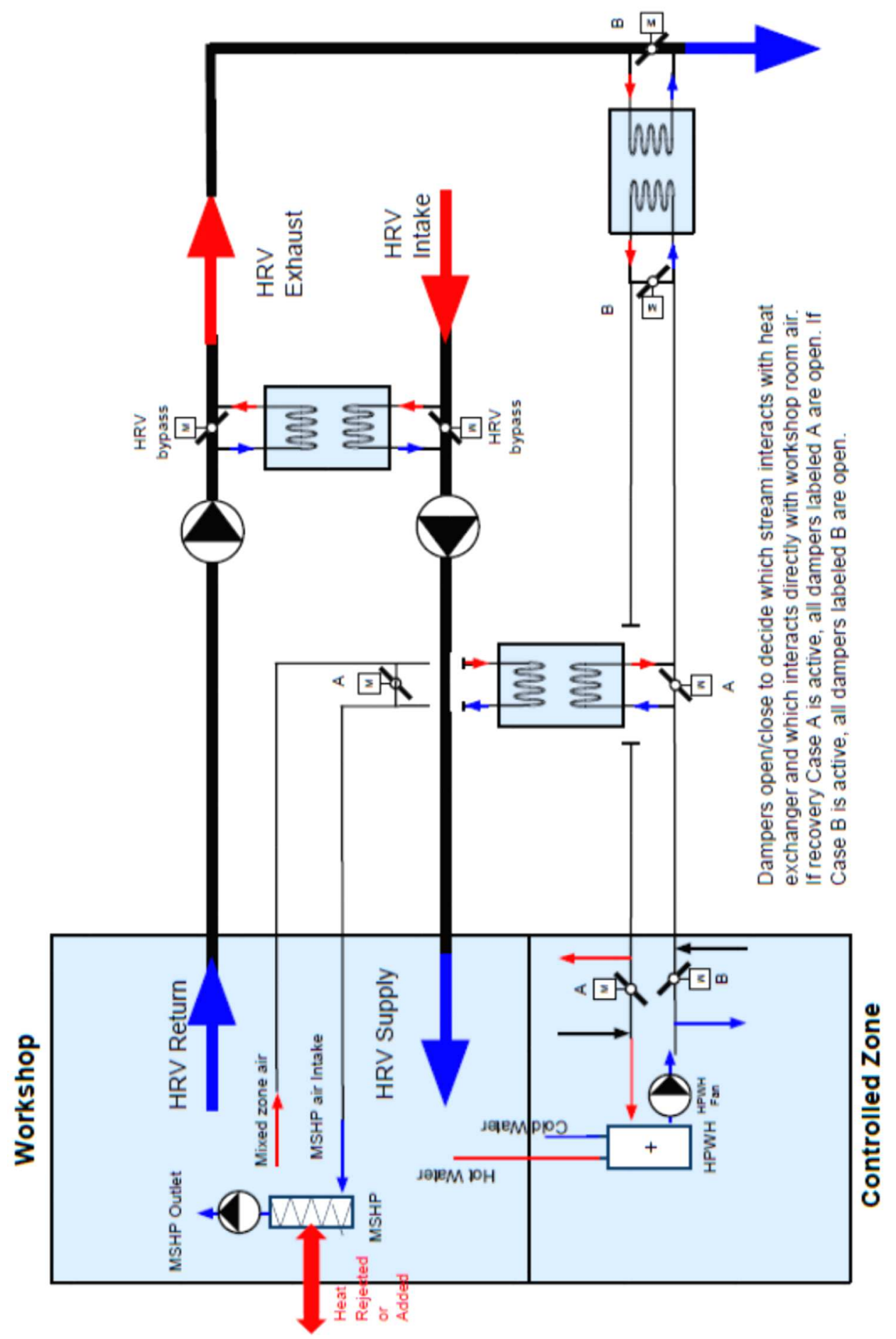

Figure 2-8 Case C: Combined strategies of Case A and Case B 


\subsubsection{Major Components, Assumptions, and Limitations}

The approach to implement these heat recovery designs is fairly straightforward. An additional sensible heat exchanger object and connections to the relevant equipment were added. The details of the HRV, HPWH, and add on heat exchangers are shown in Appendix A. The HRV exhaust fan, MSHP fan and the HPWH fan fulfill all the needs for prime movers for the air.

There are controls in the form of setpoints and usage schedules for the Heat Recovery Ventilator, Mini-Split Heat Pump, and Heat Pump Water Heater. Any additional heat recovery is done every hour of every day. In Case $\mathrm{C}$ a choice is made each month to switch from one heat recovery mode to the other. Implementing appropriate "smart" differential controls for this type of heat recovery is complex. The purpose of this model is to see if there will be savings even in a simple add-on to a typical HVAC configuration without needing a specialized Direct Digital Control (DDC). This model will not reflect all of possible savings from heat recovery controlled at an hourly level, nor does it account for the possibility of choosing outdoor air as a heat source or sink. 


\subsection{Analysis Approach}

\subsubsection{Analysis Overview}

The analysis in this study has two general categories: simulated energy consumption for Passive House models and cost analysis to determine the financial feasibility for each case in the chosen climates. This assists in the decision making process of whether or not to employ a heat recovery strategy.

\subsubsection{Heat Recovery Experimentation with Energy Model}

The energy model has several electrical end uses of interest: fans, heating, cooling, heat recovery, and hot water. These values were determined on a monthly basis for the Base Case, Case A, and Case B. Case C will be determined afterward since it is simply the ideal schedule choice for a given month between $A$ and $B$ based on the simulated energy consumption for Case $A$ or Case B. The energy use for the alternate cases was subtracted from the Base Case. This method calculates the energy savings from employing heat recovery. It is possible to have negative savings if the energy use for a given category was higher than the Base Case. Although it is informative to see the differences in each individual end use from one case to another, it is the sum of the savings that matters for determining the value of a choice.

\subsubsection{Cost Analysis}

Equipment lifespan, inflation rates, interest rates and initial equipment 
costs factor into the present worth of an energy savings choice. Although a simply payback calculation may be sufficient (See Equation 1), it is better to use the present worth equations to determine the explicit monetary value of a choice. Equation $\mathbf{2}$ is the total present worth of an investment.

$$
\begin{aligned}
& \text { Payback Period }=\frac{\text { Investment Cost }}{\text { Yearly Savings }} \\
& P=A\left[\frac{(1+i)^{N}-1}{i(1+i)^{N}}\right]+G\left[\frac{(1+i)^{N}-i N-1}{i^{2}(1+i)^{N}}\right]-C
\end{aligned}
$$

Here, $A$ is the annual savings, $G$ is the annual Inflation cost, $C$ is the initial investment cost, $\mathrm{i}$ is the interest rate, and $\mathrm{N}$ is the lifetime of the equipment in years. We use inflation rates and interest rates that reflect the norm in the Western United States [10]. The billing rates used reflect the mean residential price as stated by local utilities. Portland prices have a set rate for consumers using less than $1000 \mathrm{kWh}$. Phoenix has varying rates throughout the year, so the rates where averaged to a mean annual value. Fairbanks has only a single listed rate for residential consumers. All rates are summarized in Table 2-3. 
Table 2-4 Electric utility billing rates for chosen simulation cities

Region and Electric Utility Company

Billing Rate $(\$ / k W h)$

Portland OR, PGE [11]

0.10320

Fairbanks Alaska, GVEA [12]

0.19497

Phoenix, SRP [13]

0.10257

Interest rates and inflation are variable not only for every country, but for regions within a country. As such the values selected for analysis can be somewhat arbitrary. For the purposes of this study, the mean predicted energy inflation rate from 2010-2030 in the Western states (includes OR, AZ, and AK) is used. The interest rate is a typical savings account interest rate because the homeowner would pay this cost out of pocket. This does not account for the user taking a mortgage loan to pay for the upgrade. The lifetime of the equipment will be set at 20 years which is a typical replacement rate for mechanical equipment. This data is summarized in table 2-4.

Table 2-5 Summary of cost analysis metrics

Cost analysis metric

Metric Value

Project Life (years)

20

Interest Rate (\%) [14]

4

Inflation Rate (\%) [15]

2.56

Installation cost varies based on availability of equipment and local labor prices. The mechanical designs presume that an HRV, HPWH, and MSHP will be 
installed. If they are installed relatively close to each other in the floor plan the added cost of ducting would be fairly low. The only added equipment would be an added sensible heat exchanger for Cases $A$ and $B$, and a second heat exchanger with some added damper controls for Case $C$. The major cost is the sensible heat exchanger. These typically come as part of an HRV with two electric fans which contribute substantially to the cost and are not needed in this scenario. The assumption made for this study is that an off-the-shelf HRV minus the fans could be used, and that the installation would be a part of the initial HVAC installation upon building the house. Alternatively, this could be considered an add-on feature for an HRV already on the market. Altogether with parts and labor, the added cost would come out to about $\$ 700$ with a $10 \%$ price increase for Fairbanks [16] [17]. This calculation is crude but it gives this study a reasonable starting point. The cost can be adjusted if need be as part of future work. 


\section{Results}

The results of this study are presented in two sections: simulation data and cost analysis data. Case A performed as expected with significant savings over winter months in all climates. Case B had some surprising energy outcomes when examining the Phoenix and Fairbanks houses. They performed as near opposites with Fairbanks seeing the greatest benefit in summer, while Pheonix saw the greatest benefit in the non-summer months.

\subsection{Simulation Data}

This data was generated from EnergyPlus simulations with the output summary of EndUseEnergyConsumptionElectricityMonthly. This section contains total energy use summaries as well as the HVAC end use energy for Portland. The end use energy data for the Fairbanks and Phoenix houses are in Appendix B

\subsubsection{Baseline Case Simulation Results}




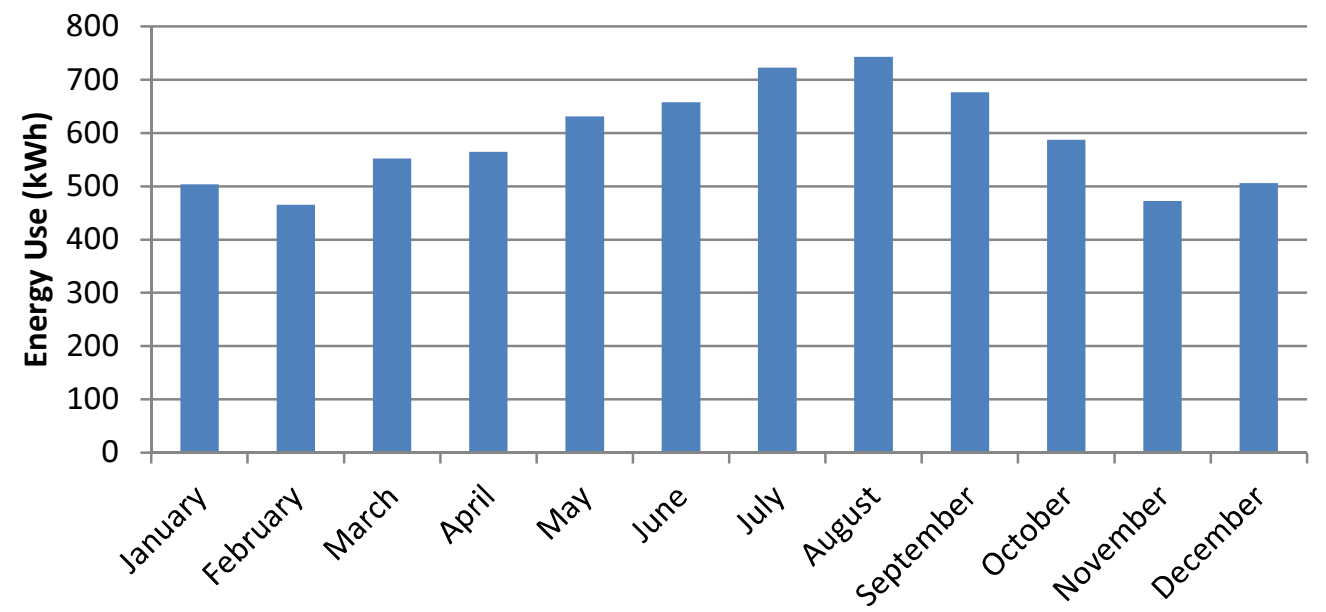

Figure 3-1 Baseline Case energy consumption for Passive House model in Portland Oregon

The total monthly energy consumption for the Baseline Case in Portland

Oregon is summarized in Figure 3-1. Annual total consumption of electricity is $7094 \mathrm{kWh}$.

\subsubsection{End Use Energy Savings for Portland Oregon}

End use energy savings summaries for fans (Figure 3-2), cooling (Figure 3-

3), heat recovery (Figure 3-4) and domestic hot water (Figure 3-5). It should be noted that the savings and penalties are slight for all end uses except domestic

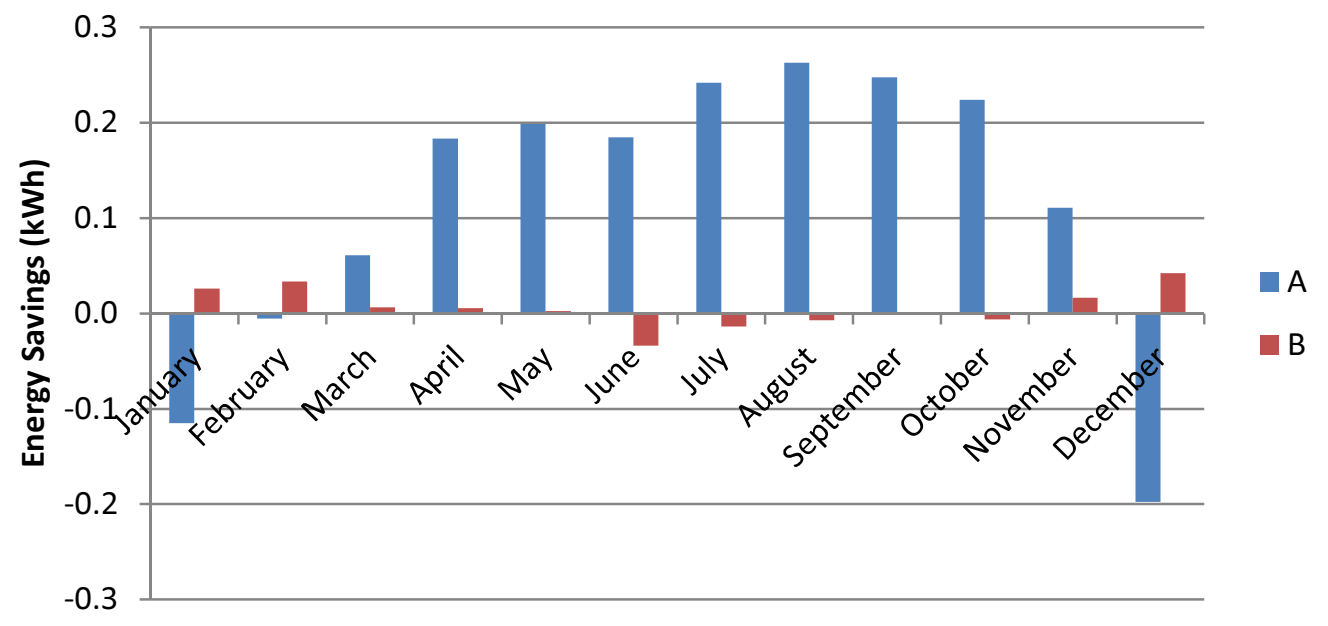

Figure 3-2 Energy savings compared to the Baseline Case for fans in Portland Oregon 
water heating for Case A, and heat recovery for Case B

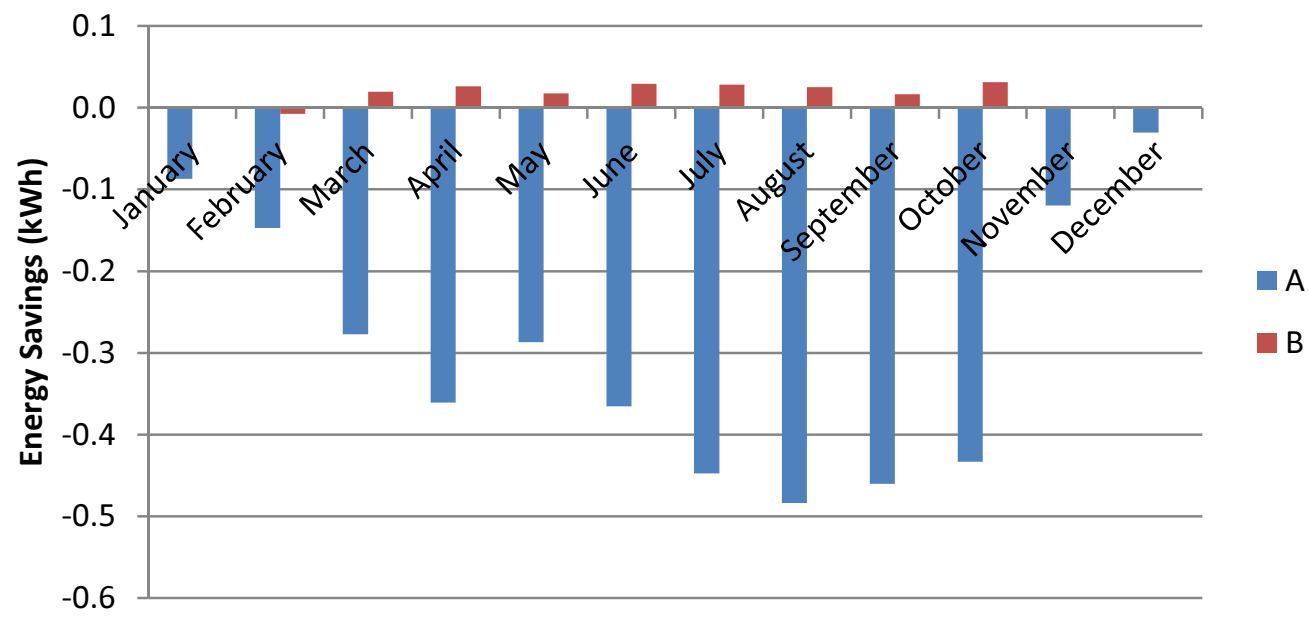

Figure 3-3 Energy savings compared to the Baseline Case for cooling in Portland Oregon

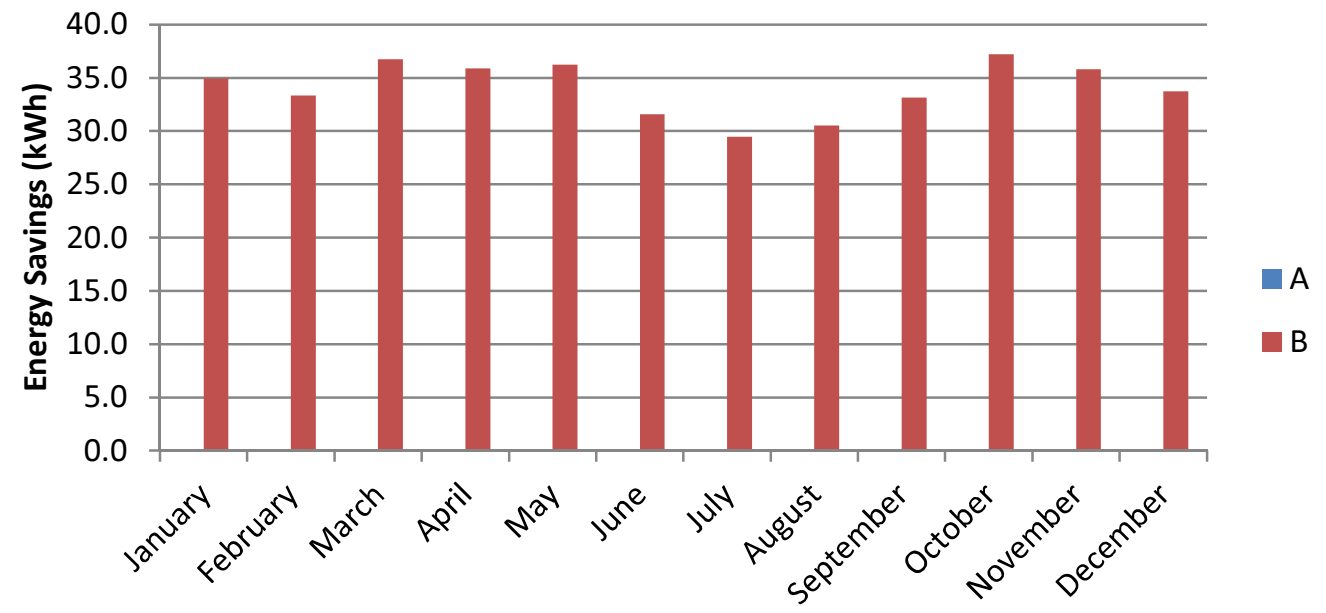

Figure 3-4 Energy savings compared to the Baseline Case for heat recovery in Portland Oregon 


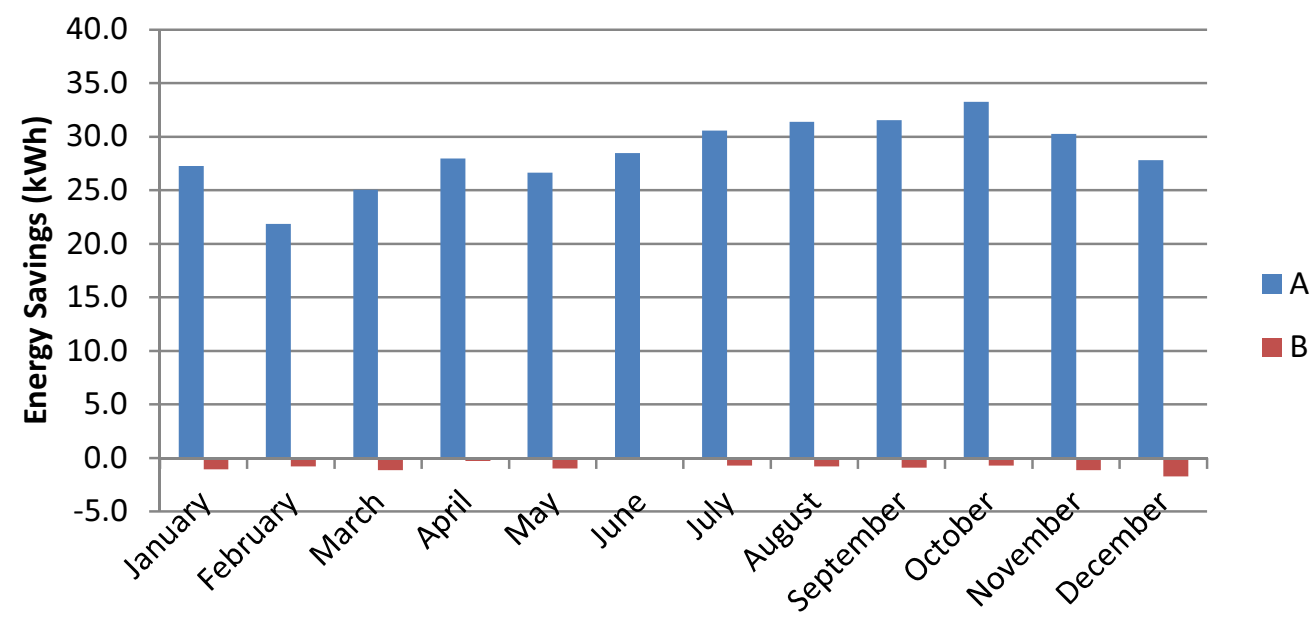

Figure 3-5 Energy savings compared to the Baseline Case for hot water in Portland Oregon

\subsubsection{Total Energy Savings for all Simulated Cities}

When the total savings on energy consumption is tallied for Case $A$ and Case B, it is clear from Figure 3-6 that Case B is the best option for Portland. Case A performs best overall in Fairbanks although the summer months in

Figure 3-7 show a slight benefit preference for case B. Case A has fairly uniform benefits in Phoenix throughout the year as seen in Figure 3-8. Case B for Phoenix demonstrates an overall penalty during summer but a benefit the rest of the year. 


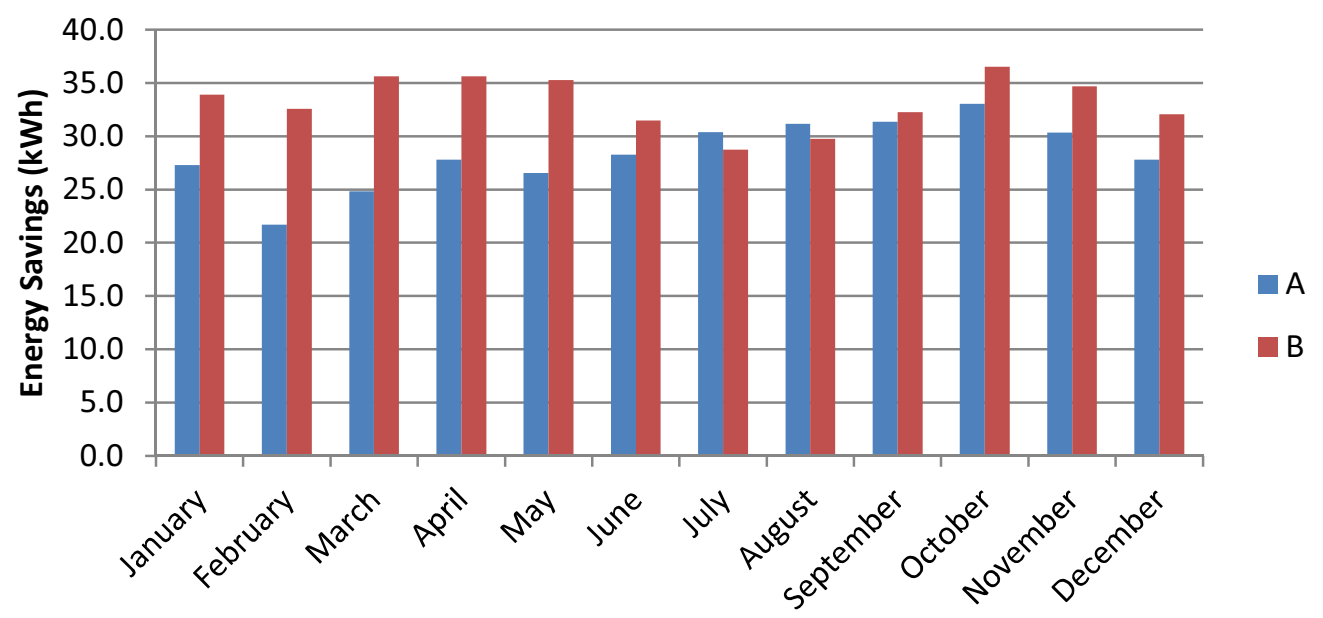

Figure 3-6 Total Energy savings from Baseline Case in Portland Oregon

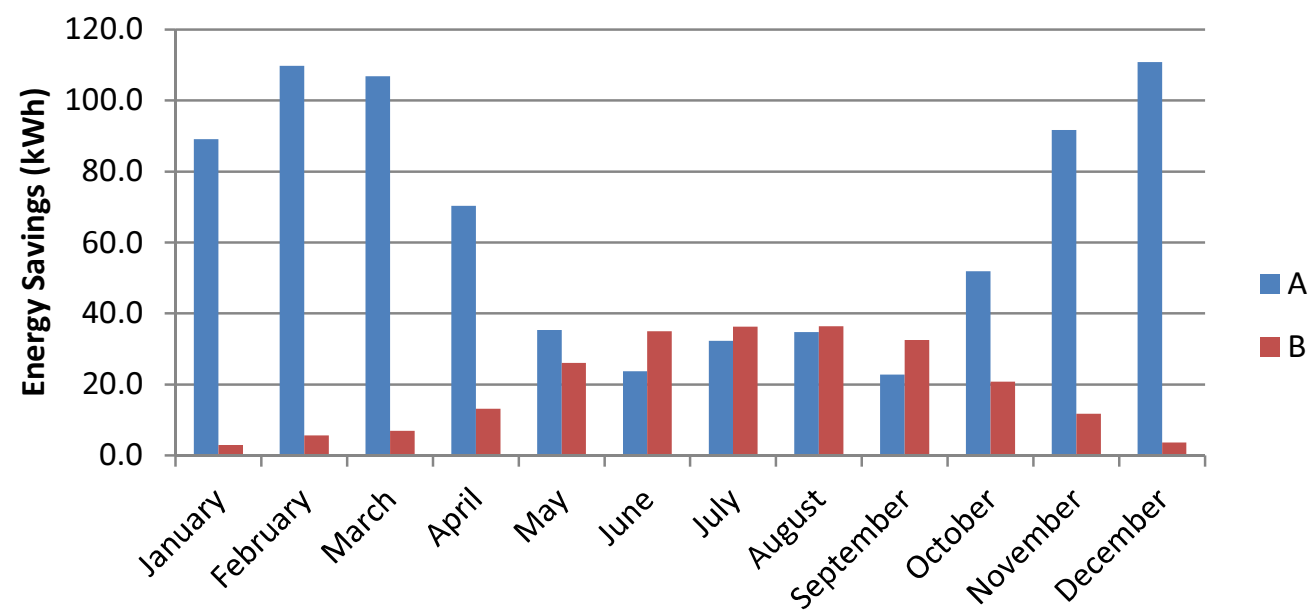

Figure 3-7 Total energy savings compared to Baseline Case in Fairbanks Alaska 


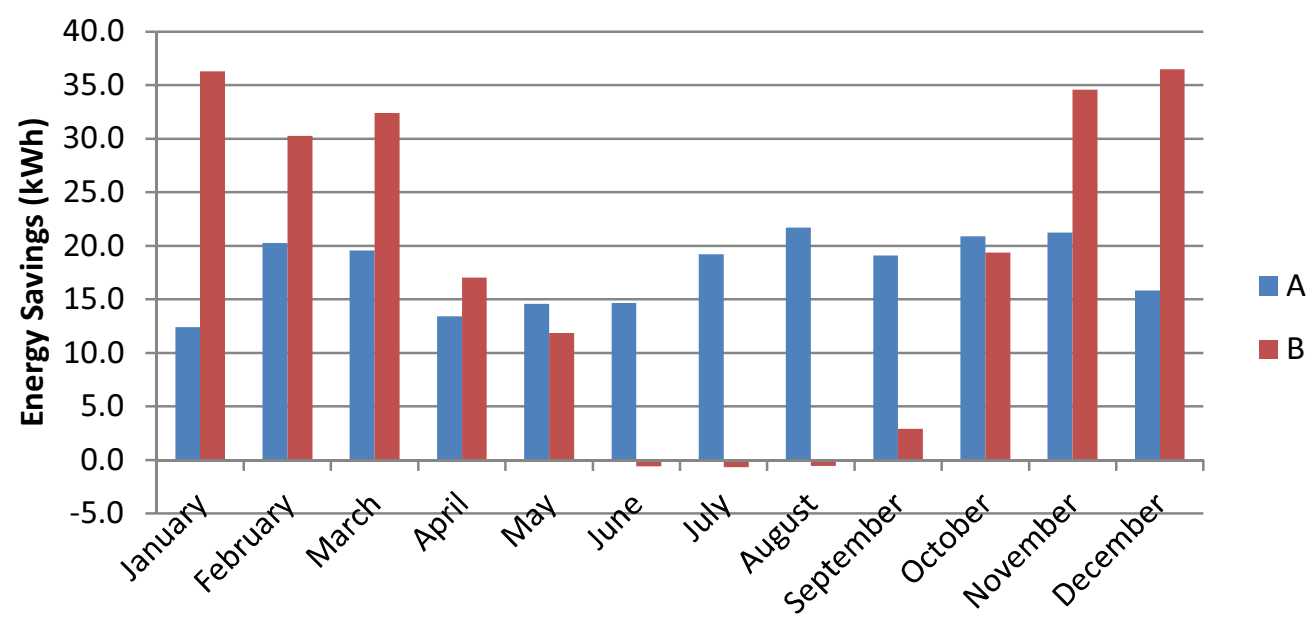

Figure 3-8 Total energy savings compared to Baseline Case in Phoenix Arizona

\subsection{Cost-Benefit Data}

These data were generated by summarizing the annual energy savings for Case $A$ and Case $B$ in each climate. Case $C$ was generated by choosing the highest savings from month to month. A rough equipment cost was calculated with mechanical cost data and an equipment catalog. Case A and B would cost roughly the same to implement while Case $\mathrm{C}$ would cost about twice as much because it is effectively the implementation of both Case A and Case B. Both a simple payback and lifecycle Benefit were calculated from Equations $\mathbf{1}$ and $\mathbf{2 .}$ The lifecycle benefit accounts for inflation and interest (discount) rates for the homeowner and calculates the present worth of an investment. Case $\mathrm{C}$ did not show sufficient benefit in any climate to make it worthwhile from purely an investment standpoint. None of the simulated strategies yielded an investment benefit for Phoenix (Table 3-3). Case B showed a net positive investment value for both Portland (Table 3-1) and Fairbanks (Table 3-2). The investment value 
was highest for Case B in Portland and Case A had the highest value in Fairbanks.

Table 3-1 Cost-benefit results for Portland Oregon

\begin{tabular}{|c|c|c|c|}
\hline & PORTLAND A & PORTLAND B & PORTLAND C \\
\hline ANNUAL ENERGY SAVINGS (KWH) & 340.5 & 398.5 & 401.5 \\
\hline ANNUAL SAVINGS (\$) & 35.13 & 68.90 & 69.42 \\
\hline INVESTMENT COST (\$) & 700 & 700 & 1400 \\
\hline SIMPLE PAYBACK (YEARS) & 19.9 & 17.0 & 33.79 \\
\hline LIFECYCLE BENEFIT (\$) & -81.39 & 24.10 & -670.43 \\
\hline
\end{tabular}

Table 3-2 Cost-Benefit results for Fairbanks Alaska

FAIRBANKS A FAIRBANKS B FAIRBANKS C

\begin{tabular}{l|llc}
\hline ANNUAL ENERGY SAVINGS (KWH) & 779.4 & 231.4 & 805.9 \\
ANNUAL SAVINGS (\$) & 151.96 & 45.11 & 157.13 \\
INVESTMENT COST (\$) & 770 & 770 & 1540 \\
SIMPLE PAYBACK (YEARS) & 5.07 & 17.07 & 9.80 \\
LIFECYCLE BENEFIT (\$) & 1905.54 & 24.32 & 1226.51
\end{tabular}

Table 3-3 Cost-Benefit data for Phoenix Arizona

\begin{tabular}{l|lll}
\multicolumn{2}{c}{ PHOENIX A } & PHOENIX B & PHOENIX C \\
\hline ANNUAL ENERGY SAVINGS (KWH) & 212.8 & 219.3 & 297.1 \\
\hline ANNUAL SAVINGS (\$) & 21.83 & 22.49 & 30.47 \\
\hline INVESTMENT COST (\$) & 700 & 700 & 1400 \\
\hline SIMPLE PAYBACK (YEARS) & 32.1 & 31.1 & 45.9 \\
\hline LIFECYCLE BENEFIT (\$) & -315.73 & -303.94 & -863.44 \\
\hline
\end{tabular}




\section{Discussion}

The discussion of the results is in four parts: How heat recovery Case $A$ and Case B performed, how these results compare to other studies, what are some of the drawbacks of how this study was performed, how could this study be done differently.

\subsection{Heat Recovery Performance}

The performance of a heat recovery strategy must be judged by how it created energy savings compared to the Baseline Case, and how these energy savings translated to investment value for the home owner.

\subsubsection{Analysis of Energy Data}

A summary for the total energy consumption of the Baseline Case model is presented in Figure 3-1. The total site energy consumption per square foot is $48 \mathrm{kWh} / \mathrm{m}^{2}$ per year, and the total site heating and cooling energy is $12 \mathrm{kWh} / \mathrm{m}^{2}$ per year. This energy consumption profile is well within the acceptable limits for a Passive House.

Alternate Cases A and B demonstrated very little change in fan energy consumption. Figure 3-2 shows the savings in fan energy for Case $A$ and Case $B$ in Portland. The savings for case A and the penalty for case B are very small, on the order of a kWh for the whole year. The savings in Case A is from the reduced demand on the air side of the HPWH compressor thus resulting in less air needing to be moved. The fan penalty in Case B is slight, and comes from the HPWH compressor needing to work harder since its heat source is household air 
which typically has a lower enthalpy than the HRV exhaust. In addition the MSHP fan needs to work harder to overcome the pressure drop from the added sensible heat exchanger. Similar results are observed for the simulations for Fairbanks and Phoenix (Figures 7-1, 7-2). The benefit in Case A for Phoenix is about 2 times larger than that for Portland. The simulation of Case A for Fairbanks shows a net penalty of roughly $6 \mathrm{kWh}$ because the exhaust temperatures for the HRV were typically lower than the workshop air temperature. The results for Case B were nearly the same across all climates. Cooling energy was not greatly affected by either alternate case. Figure 3-3 shows the energy savings for cooling energy compared to the Baseline Case for Cases A and B in Portland. Case A has penalty of $4 \mathrm{kWh}$ per year while case B has a savings of less than a kWh. The results for Phoenix show slightly larger penalty of $7 \mathrm{kWh}$ per year for Case A, and the Fairbanks penalty is $2 \mathrm{kWh}$ per year (Figures 7-3, 7-4). Case B is roughly the same for all climates.

There was a substantial change in total heat recovery energy by exchanging heat between cold HPWH exhaust energy with indoor air. Figure 3-4 shows energy savings for heat recovery compared to the baseline for Cases A and B. Case A has no effect whatsoever on heat recovery energy while case B shows a savings of $409 \mathrm{kWh}$. This accounts for nearly all of the energy savings for case B. The results are similar for Fairbanks and Phoenix which showed a savings of $252 \mathrm{kWh}$ and $229 \mathrm{kWh}$ respectively (Figures 7-5, 7-6). The reason for the savings in Case B is not immediately apparent. It should be noted that the 
greatest savings for Phoenix was in the non-summer months while the greatest savings for Fairbanks was during the summer. This indicates that the savings for Case B comes from longer operation hours for the HRV bypass mode which reduces the total HRV energy consumption by reducing the pressure drop for bringing in outdoor air. The bypass activates whenever the outdoor air temperature is cooler than the return air temperature and a building is in cooling mode. This would rarely happen in a Phoenix summer which is to hot at all times from bypass mode, and would most often happen during a Fairbanks summer. Figure 7-9 shows the power use for the HRV for a hot summer day for Case B and the Baseline. The only time when both cases operate in the same fashion is during the hottest part of the day when bypass mode cannot be active. The specific effects surrounding the heat recovery savings may merit further study.

Energy consumption for domestic hot water was significantly changed by capturing waste heat from household exhaust air. Figure 3-5 demonstrates substantial savings of $342 \mathrm{kWh}$ per year in Portland by employing case A. Case B shows a small penalty of $10 \mathrm{kWh}$ per year. Fairbanks has a savings of $781 \mathrm{kWh}$ per year for case A, and the Phoenix house saves $219 \mathrm{kWh}$ per year. The positive effect of feeding heat to the HPWH compressor intake is clear. It makes intuitive sense that adding heat to the reservoir that the HPWH draws from would improve its efficiency and therefore its energy consumption. It also makes sense that the greatest improvement by employing case $A$ is for colder climates where the conditions would penalize a standalone HPWH even more than a hot climate. 
The penalty for coupling the cold exhaust to the household air is not as obvious. Note that the net energy penalty for water heating under Case B is the same in Phoenix as it is in Portland (Figure 7-7), while the penalty is 20 kWh in Fairbanks (Figure 7-8). It is likely it is not as useful to the efficiency of the HPWH to have a warmer cold reservoir to dump heat to as opposed to having a warmer hot reservoir. It would merit further study to examine the effects on efficiency of connecting the cold air exhaust of HPWH to different temperature reservoirs.

The overall energy consumption data for each case in each climate shows that there may be some benefit to switching between recovering heat for hot water from house exhaust, or using the HPWH cold air to improve heat recovery in the house (see Figures 3-6, 3-7, 3-8). It should be noted that in Portland, improving household heat recovery has the greatest benefit regardless of the month. Phoenix and Fairbanks do best for most of the year under Cases B and A respectively, while seeing a changeover in best monthly benefit during the summer. There is no question that employing a Case $C$ would bring an Energy benefit to the Fairbanks and Phoenix houses, only a long term cost analysis will tell whether or not it is a good investment for the homeowner.

\subsubsection{Analysis of Cost Data}

Tables 3-1, 3-2 and 3-3 provide summaries of the costs and benefits of employing each heat recovery strategy. The first thing one should note is that none of these strategies would be worthwhile in the Phoenix House. This is 
because the Energy savings are too low, and the cost of electric energy in

Phoenix is inexpensive at $\$ 0.10 / \mathrm{kWh}$. This ends up making the payback period 10 years greater than the lifetime of the equipment, and the lifetime benefits are negative. The Portland house would payback at 20 years for case A, and 10 for Case B with a lifetime penalty of $\$ 81$ and benefit of $\$ 24$ respectively. Fairbanks shows the most promise with a payback of 5 years for Case A and a lifetime benefit of $\$ 1906$.

Case $C$ is problematic. Although the energy savings for Case $C$ are the highest in the Fairbanks house, the lifetime benefit is less at $\$ 1227$ because of the added equipment cost. If energy savings were the only goal then it would be worthwhile. If a design were on the brink of meeting a strict certification like the Passive House standard then it could be employed. From strictly a cost standpoint it makes sense to choose either Case A or Case B depending on the climate, and local energy costs.

\subsection{Comparison to other studies}

A study at Oakridge National Laboratory by Thomlinson et al showed the energy saving potential from a combined HPWH and indoor heat pump system [18]. Excess hot water was used to heat indoor air. A compression cycle used the cold output from the HPWH to cool the indoor air. Although this system showed a high theoretical efficiency of 19.6 SEER for heating, cooling, and hot water; the 
prototype has not yet been developed. This study does indicate that "soft integration" of heat pump water heaters with waste heat producers like refrigerators and dryers is a well-established practice with proven results. This "soft integrated" approach is done by placing the HPWH in the proximity of the waste heat producer. This differs significantly from the approach taken in this study which aimed to directly interface the HPWH with existing heat sources and sinks. In addition this study focused on evaluating a Passive House model instead of a typical residence.

Exhaust air heat recovery in Buildings by Fehrm et al investigates the energy savings for a variety of cases in Sweden that employ an exhaust air heat pump system to reuse waste heat [19]. The overall device designs were similar to the configuration studied by Tomlinson et al in they used a series of vapor compression cycles to transfer the heat. The study shows savings of up to $31 \%$ in some cases. It is clearly stated that these systems are made financially viable by a combination of regulations on residential energy use and government subsidies.

\subsection{Potential Drawbacks}

Although using household exhaust and indoor air streams shows promise in improving overall efficiency for a house; there is a significant barrier of $10 \%$ $20 \%$ added construction costs for a Passive House. Although the savings in the 
energy models for this study were clearly present, those energy savings would not be possible without added investment. The success of the cost analysis is strongly dependent on the price of electricity as well as the initial added cost of installation. Such a heat recovery system is not on the market and this makes the equipment cost challenging to estimate. It would require substantial analysis from an experienced mechanical designer and contractor to determine the actual initial cost of installation. The novelty alone would make this task more expensive than the costs estimated in previous sections.

\subsection{What could be done differently?}

To get a greater benefit out of Case A or B, a digital control system could be employed. Although this would add significant installation cost, there is potential to increase savings. A "smart" digital control would maximize the benefit on a short term basis and reduce losses by only employing heat recovery when it is needed. The Trekhaus only has a digital control for the MSHP which controls heating and cooling. It would likely see a savings if there were a digital controller for the HRV that changed flow rates based on occupancy and infiltration through open windows and doors. The HRV is instead controlled by the building occupants. The reason that this has not been done is that the savings by having such a control does not outweigh the cost for that particular DDC application.

It may be worthwhile to combine Case A or B with an outdoor air loop to 
provide the option of exchanging air with the outside. This would require some additional added controls, but an additional heat source/sink could add some additional efficiency to domestic hot water heating or heat recovery.

In addition, a clear benefit of employing these heat recovery systems only seems to manifest in a mild climate for Case B, or a cold climate for Case A. There are a fairly large number of certified Passive Houses in Oregon and Illinois so there may be hope for these heat recovery strategies being employed in the US especially if the climate is mostly heating dominated. There is an even greater possibility for this being effective in northern Europe or Scandinavia where Passive houses are common and Energy prices can be up to three times higher for residential consumers [20]. 


\section{Conclusion}

This study evaluates the effects of using exhaust heat recovery to improve HPWH efficiency, and cold HPWH exhaust recovery to improve household HVAC efficiency. The end result was that exhaust air heat recovery design improvement paid back in 5 years in Fairbanks Alaska and 12 years in Portland Oregon while it would not pay back in Phoenix Arizona. Using cold air heat recovery paid back in 10 years in Portland, 15 years in Fairbanks, and would not pay back in Phoenix. These results would vary with different cost data.

The Passive House standard requires innovation to achieve its challenging energy consumption goal of $120 \mathrm{kWh} / \mathrm{m}^{2}$ per year. As such, finding cost effective improvements beyond the typical energy saving HVAC and appliances is difficult. Even what appears to be a substantial savings of $\$ 60$ per year will not mean much to the consumer if they have to make an unsubsidized investment at a net penalty over the life of the installed equipment. In addition, the savings will not be the same for all houses and locations. In this study, it was observed that a Passive House in Fairbanks Alaska would save a substantial amount of money with a heat recovery improvement while the same house in Portland received a mediocre benefit. This was due to a combination of slightly different energy prices and substantially different climates for the same improvement.

Ultimately, no one solution will always be the answer.

Some of the results need further examination: such as the specific benefit 
to heat recovery when using cold air exhaust, and the associated water heating penalty. It would also be worthwhile to see how an outdoor air loop and a digital controller would affect these heat recovery strategies. Further investigation into sensible waste heat recovery strategies shows great promise for improving efficiency in Passive Houses and other high performance buildings. 


\section{References}

[1] U.S. Department of Energy Office of Energy Efficiency and Renewable Energy, United States, "Buildings energy data book," 2011. [Online]. Available: http://www.btscoredatabook.net.

[2] Energy Star, "Energy strategies for buildings\&plants," [Online]. Available: http://www.energystar.gov/buildings/facility-owners-andmanagers/existing-buildings/use-portfolio-manager/understandmetrics/difference. [Accessed 2014].

[3] Passive House Institute US, What is a Passive House?, 2011.

[4] D.J. Sailor, J. Lauck, "Evaluation of Phase Change Materials for Improving thermal comfort in a Super-Insulated Residential Building," Energy and Buildings, no. 79, pp. 32-40, 2014.

[5] D.J. Sailor, J. Lauck, S. Rodriguez, "In Situ Evaluation of vangaurd technologies for high performance residential buildings," in ASME 2013 Summer Heat Transfer Conference, Minneapolis, 2013.

[6] B. Sparn, K. Hudson, and D. Christenson, "Laboratory Performance Evaluation of Residential Integrated Heat Pump Water Heaters," NREL, Golden, 2011.

[7] American Society of Heating, Refrigerating and Air-Conditioning Engineers, 2009 ASHRAE Handbook: Fundamentals, Atlanta, GA: ASHRAE, 2009.

[8] Earnesto Orlando Laurence Berkly National Laboratories University of Illinois, "Getting Started with Energy Plus," U.S. Department of Energy, 2013.

[9] J. Lauck, PCM in Super-Insulated Buildings, Portland: Portland State University, 2013.

[10] A. Rushing, J. Kneifel, B. Lippiatt "Energy Price Indices and Discount Factors For Life-Cycle Cost Analysis," in NIST Handbook 135, US NIST, 2010.

[11] Portland General Electric Company, Schedule 7 Residential Service, Portland: Portland General Electric Company, 2012.

[12] Golden Valley Electric Association, "Rates," Golden Valley Electric Association, 0203 2014. [Online]. Available:

http://www.gvea.com/rates/rates.

[13] SRP, "Frequently asked questions about the basic plan," SRP, 2014. [Online]. Available:

http://www.srpnet.com/prices/home/basicfaq.aspx\#1.

[14] BECU, "Cecking and Savings," 201405 2014. [Online]. Available: 
http://www.becu.org/personal/checking-savings.aspx.

[15] Standard \& Poors, "US Inflation Rate By Year," 1042014.

[Online]. Available: http://www.multpl.com/inflation/table.

[16] P. R. Waier, "Heating Ventilation and AC," in RSMeans Building Construction Cost Data, 2012, pp. 496-531.

[17] Grainger, "Heat \& Energy Recovery Ventilators," [Online].

Available: http://www.grainger.com/category/heat-energy-recoveryventilators/central-equipment/hvac-and-refrigeration/ecatalog/ $\mathrm{N}-\mathrm{jq} 4$.

[18] J.J. Tomlinson, C.K. Rice, E. Baskin, "Integrated Heat Pumps For Combined Space Conditioning and Water Heating," in 8th IEA Heat Pump Conference, Tokyo, 2005.

[19] Mats Fehrm, Wilhelm Reiners, Matthias Ungemach, "Exhaust air heat recovery in buildings," International Journal of refrigeration, no. 25, pp. 439-449, 2002.

[20] European Commission, "Energy Prices and Costs in Europe," Brussels, 2014. 


\section{Appendix A - EnergyPlus}

The following figures are Base Case HVAC equipment objects in

EnergyPlus that are the most critical to replicating the energy model for the

Baseline Case. These include the packaged terminal heat pump, heat recovery

ventilator, heat recovery ventilator controller, Package terminal heat pump

heating and cooling coils, fans, heat pump water heater, heat pump water

heater coil, heat recovery ventilator sensible heat exchanger, equipment

connection list, and node list.

\begin{tabular}{|c|c|c|}
\hline [0001] ZoneHVAC:PackagedT erminalHeatPump & $\checkmark$ & $\begin{array}{l}\text { umpl, supplemental heatıng co } \\
\text { ved-position outdoor air mixer. }\end{array}$ \\
\hline Field & Units & Obj1 \\
\hline Availability Schedule Name & & Always On Discrete 1 \\
\hline Air Inlet Node Name & & PTHP Indoor Air Intake \\
\hline Air Outlet Node Name & & PTHP Conditioned Air Outlet \\
\hline Outdoor Air Mixer Object Type & & OutdoorAir:Mixer \\
\hline Outdoor Air Mixer Name & & PTHP 0A Mixer \\
\hline Supply Air Flow Rate During Cooling Operation & $\mathrm{m} 3 / \mathrm{s}$ & 0.165 \\
\hline Supply Air Flow Rate During Heating Operation & $\mathrm{m} 3 / \mathrm{s}$ & 0.165 \\
\hline Supply Air Flow Rate When No Cooling or Heating is $\mathrm{N} \varepsilon$ & $\mathrm{m} 3 / \mathrm{s}$ & 0.165 \\
\hline Outdoor Air Flow Rate During Cooling Operation & $\mathrm{m} 3 / \mathrm{s}$ & 0 \\
\hline Outdoor Air Flow Rate During Heating Operation & $\mathrm{m} 3 / \mathrm{s}$ & 0 \\
\hline Outdoor Air Flow Rate When No Cooling or Heating is $\mathrm{A}$ & $\mathrm{m} 3 / \mathrm{s}$ & 0 \\
\hline Supply Air Fan Object Type & & Fan:OnOff \\
\hline Supply Air Fan Name & & PTHP supply Fan \\
\hline Heating Coil Object Type & & Coil:Heating:DX:SingleSpeed \\
\hline Heating Coil Name & & HP Heating Coil \\
\hline Heating Convergence Tolerance & dimensionless & 0.001 \\
\hline Minimum Dutdoor Dry-Bulb Temperature for Compressor & C & -8 \\
\hline Cooling Coil Object Type & & Coil:Cooling:DX:SingleSpeed \\
\hline Cooling Coil Name & & HP Cooling Coil \\
\hline Cooling Convergence Tolerance & dimensionless & 0.001 \\
\hline Supplemental Heating Coil Object Type & & Coil:Heating:Electric \\
\hline Supplemental Heating Coil Name & & 0S:Coil:Heating:Electric 5 \\
\hline Maximum Supply Air Temperature from Supplemental $\mathrm{H}_{\ell}$ & $\mathrm{C}$ & autosize \\
\hline Maximum Dutdoor Dry-Bulb Temperature for Supplemer & C & 21 \\
\hline Fan Placement & & DrawThrough \\
\hline Sunnlu Air Fan Mneratinn Mnde Sirhertule Name & & \\
\hline
\end{tabular}

Figure 6-1 EnergyPlus object ZoneHVAC:PackagedTerminal Heatpump 


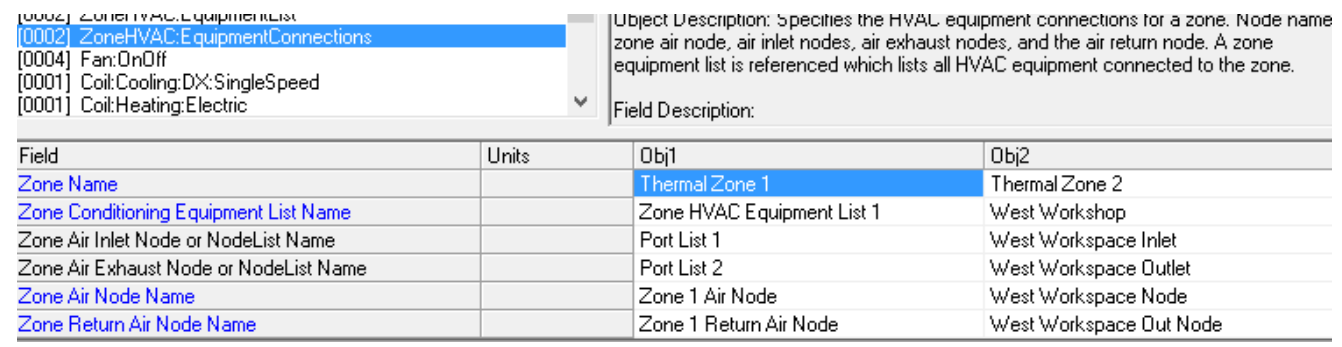

Figure 6-2 EnergyPlus object ZoneHVAC:EquipmentConnections

\begin{tabular}{|c|c|c|c|}
\hline Field & Units & Obji & Obi2 \\
\hline Name & & Port List 1 & Port List 2 \\
\hline Node 1 Name & & PTHP Conditioned Air Outlet & PTHP Indoor Air Intake \\
\hline Node 2 Name & & HRV Supply Fan Dutlet & HRV Relief Air Outlet Node \\
\hline
\end{tabular}

Figure 6-3 EnergyPlus objects NodeList

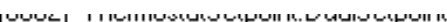

[0001] ZoneHVAC:PackagedT erminalHeatPump 00011 ZoneHVAC:EnerguPecowerwiventilator supply air fan, exhaust air fan and an optiona of the supply air leconomizer or free cooling o

\begin{tabular}{|l|l|l|}
\hline Field & Units & Obi1 \\
\hline Name & & Heat Recovery Ventilator \\
\hline Availability Schedule Name & & Always On \\
\hline Heat Exchanger Name & & HRV HX \\
\hline Supply Air Flow Rate & $\mathrm{m} 3 / \mathrm{s}$ & 0.048611111 \\
\hline Exhaust Air Flow Rate & $\mathrm{m} 3 / \mathrm{s}$ & 0.048611111 \\
\hline Supply Air Fan Name & & HRV Supply Fan \\
\hline Exhaust Air Fan Name & & HRV Exhaust Fan \\
\hline Controller Name & & ERV Economizer \\
\hline Ventilation Rate per Unit Floor Area & $\mathrm{m} 3 / \mathrm{s}-\mathrm{m} 2$ & \\
\hline Ventilation Rate per Dccupant & $\mathrm{m} 3 / \mathrm{s}-\mathrm{person}$ & \\
\hline Availability Manager List Name & & Air Loop HVAC 1Availability Manager List \\
\hline
\end{tabular}

Figure 6-4 EnergyPlus object ZoneHVAC:EnergyRecoveryVentilator 


\begin{tabular}{|c|c|c|}
\hline [0001] ZoneHVAC:Energupecovery Ventilator:Controller & $\checkmark$ & $\begin{array}{l}\text { Field Description: } \\
\text { ID: A1 }\end{array}$ \\
\hline Field & Units & Obji1 \\
\hline Name & & ERV Economizer \\
\hline Temperature High Limit & C & 0 \\
\hline Temperature Low Limit & C & \\
\hline Enthalpy High Limit & $\mathrm{J} / \mathrm{kg}$ & \\
\hline Dewpoint Temperature Limit & C & \\
\hline Electronic Enthalpy Limit Curve Name & & \\
\hline Exhaust Air Temperature Limit & & ExhaustAirT emperatureLimit \\
\hline Exhaust Air Enthalpy Limit & & NoExhaustAirEnthalpyLimit \\
\hline Time of Day Economizer Flow Control Schedule Name & & \\
\hline High Humidity Control Flag & & No \\
\hline Humidistat Control Zone Name & & \\
\hline High Humidity Outdoor Air Flow Ratio & & 1 \\
\hline Control High Indoor Humidity Based on Dutdoor Humidit & & No \\
\hline
\end{tabular}

Figure 6-5 EnergyPlus object ZoneHVACEnergyRecoveryVentilator

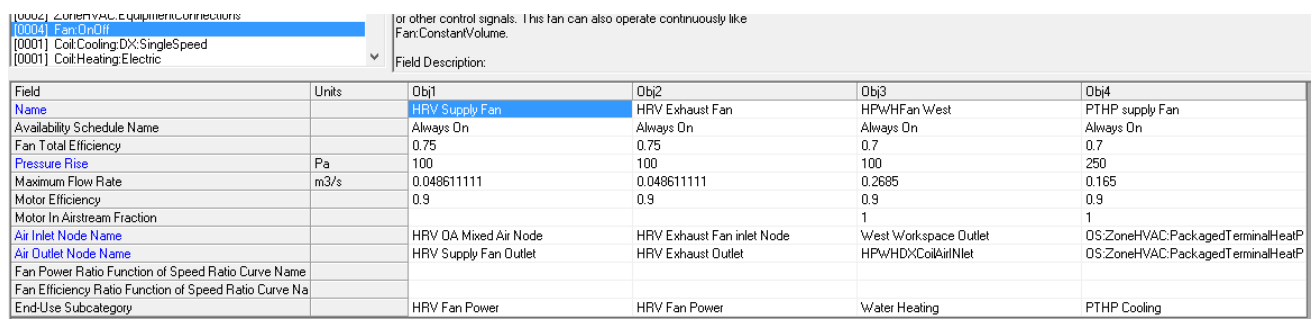

Figure 6-6 EnergyPlus objects Fan:OnOff 


\begin{tabular}{|l|l|l|}
\hline Field & Units & Obj1 \\
\hline Name & & HP Cooling Coil \\
\hline Availability Schedule Name & & Always On Discrete 1 \\
\hline Gross Rated Total Cooling Capacity & W & 2800 \\
\hline Gross Rated Sensible Heat Ratio & & 0.75 \\
\hline Gross Rated Cooling COP & W/W & 3.4 \\
\hline Rated Air Flow Rate & $\mathrm{m3} / \mathrm{s}$ & 0.15 \\
\hline Rated Evaporator Fan Power Per Volume Flow Rate & W/(m3/s) & \\
\hline Air Inlet Node Name & & PTHP 0A Mixed Air Node \\
\hline Air Outlet Node Name & & OS:ZoneHVAC:PackagedTerminalHeatP \\
\hline Total Cooling Capacity Function of Temperature Curve I & & HPACCoolCapFT \\
\hline Total Cooling Capacity Function of Flow Fraction Curve & & HPACCoolCapFFF \\
\hline Energy Input Ratio Function of Temperature Curve Narr & & HPACCOOLEIRFT \\
\hline Energy Input Ratio Function of Flow Fraction Curve Nar & & HPACCOOLEIRFFF \\
\hline Part Load Fraction Correlation Curve Name & & HPACCOOLPLFFPLR \\
\hline Nominal Time for Condensate Removal to Begin & s & \\
\hline Ratio of Initial Moisture Evaporation Rate and Steady S & dimensionless & \\
\hline Maximum Cycling Rate & cycles/hr & \\
\hline Latent Capacity Time Constant & s & \\
\hline Condenser Air Inlet Node Name & & \\
\hline Condenser Type & dimensionless & \\
\hline Evaporative Condenser Effectiveness & \\
\hline
\end{tabular}

Figure 6-7 EnergyPlus object CoolingCoil:DX:SingleSpeed

\begin{tabular}{|c|c|c|}
\hline Field & Units & Obji1 \\
\hline Name & & HP Heating Coil \\
\hline Availability Schedule Name & & Always On Discrete 1 \\
\hline Gross Rated Heating Capacity & W & 3192 \\
\hline Gross Rated Heating COP & W/W & 2.81 \\
\hline Rated Air Flow Rate & $\mathrm{m} 3 / \mathrm{s}$ & 0.1652 \\
\hline Rated Supply Fan Power Per Volume Flow Rate & $\mathrm{W} /(\mathrm{m} 3 / \mathrm{s})$ & \\
\hline Air Inlet Node Name & & 0S:ZoneHVAC:PackagedTerminalHeatP \\
\hline Air Outlet Node Name & & 0S:ZoneHVAC:PackagedT erminalHeatP \\
\hline Heating Capacity Function of Temperature Curve Name & & HPACHeatCapFT \\
\hline Heating Capacity Function of Flow Fraction Curve Namı & & HPACCoolCapFFF \\
\hline Energy Input Ratio Function of Temperature Curve Narr & & HPACHeatEIRFT \\
\hline Energy Input Ratio Function of Flow Fraction Curve Nar & & HPACCOOLEIRFFF \\
\hline Part Load Fraction Correlation Curve Name & & HPACCOOLPLFFPLR \\
\hline Defrost Energy Input Ratio Function of Temperature $\mathrm{Cu}$ & & HPACCoolCapFT \\
\hline Minimum Dutdoor Dry-Bulb Temperature for Compressor & C & -8 \\
\hline Outdoor Dry-Bulb Temperature to Turn On Compressor & C & \\
\hline Maximum Outdoor Dry-Bulb Temperature for Defrost Op & C & 5 \\
\hline Crankcase Heater Capacity & W & \\
\hline Maximum Dutdoor Dry-Bulb Temperature for Crankcase & C & 10 \\
\hline Defrost Strategy & & ReverseCycle \\
\hline Nefrnet Prnatral & & $\begin{array}{l}\text { Timed } \\
\text { Sneed }\end{array}$ \\
\hline
\end{tabular}




\begin{tabular}{|l|l|l|}
\hline Field & Units & Obj1 \\
\hline Name & & HFWHDXCoil \\
\hline Rated Heating Capacity & W & 2750 \\
\hline Rated COP & W/W & 3 \\
\hline Rated Sensible Heat Ratio & & 0.6956 \\
\hline Rated Evaporator Inlet Air Dry-Bulb Temperature & C & 29.44 \\
\hline Rated Evaporator Inlet Air Wet-Bulb Temperature & C & 22.22 \\
\hline Rated Condenser Inlet Water Temperature & C & 55.72 \\
\hline Rated Evaporator Air Flow Rate & $\mathrm{m} 3 / \mathrm{s}$ & autocalculate \\
\hline Rated Condenser Water Flow Rate & $\mathrm{m} 3 / \mathrm{s}$ & autocalculate \\
\hline Evaporator Fan Power Included in Rated COP & & Yes \\
\hline Condenser Pump Power Included in Rated COP & & Yes \\
\hline Condenser Pump Heat Included in Rated Heating Cape & & No \\
\hline Condenser Water Pump Power & W & 150 \\
\hline Fraction of Condenser Pump Heat to Water & & 0.1 \\
\hline Evaporator Air Inlet Node Name & & HFWHDXCoilAirlNlet \\
\hline Evaporator Air Outlet Node Name & & West Workspace Inlet \\
\hline Condenser Water Inlet Node Name & & HFWHWaterlnletNode West \\
\hline Condenser Water Outlet Node Name & & HFWHWaterOutletNode West \\
\hline Crankcase Heater Capacity & W & 100 \\
\hline Maximum Ambient Temperature for Crankcase Heater C & C & 5 \\
\hline Evaporator Air Temperature Type for Curve Objects & & WetBulbTemperature \\
\hline
\end{tabular}

Figure 6-9 EnergyPlus Object Coil:WaterHeating:AirToWaterHeatPump

\begin{tabular}{|c|c|c|}
\hline Field & Units & Obji1 \\
\hline Name & & HeatPumpWaterHeater West \\
\hline Availability Schedule Name & & Always On \\
\hline Compressor Setpoint Temperature Schedule Name & & HPWHTempSch \\
\hline Dead Band Temperature Difference & deltaC & 2 \\
\hline Condenser Water Inlet Node Name & & HFWHWaterlnletNode West \\
\hline Condenser Water Outlet Node Name & & HPWHWaterDutletNode West \\
\hline Condenser Water Flow Rate & $\mathrm{m} 3 / \mathrm{s}$ & autocalculate \\
\hline Evaporator Air Flow Rate & $\mathrm{m} 3 / \mathrm{s}$ & autocalculate \\
\hline Inlet Air Configuration & & ZoneAirOnly \\
\hline Air Inlet Node Name & & West Workspace Dutlet \\
\hline Air Outlet Node Name & & West Workspace Inlet \\
\hline \multicolumn{3}{|l|}{ Outdoor Air Node Name } \\
\hline \multicolumn{3}{|l|}{ Exhaust Air Node Name } \\
\hline \multicolumn{3}{|l|}{ Inlet Air Temperature Schedule Name } \\
\hline \multicolumn{3}{|l|}{ Inlet Air Humidity Schedule Name } \\
\hline Inlet Air Zone Name & & Thermal Zone 2 \\
\hline Tank Object Type & & WaterHeater:Mixed \\
\hline Tank Name & & HPWHT ank West \\
\hline \multicolumn{3}{|l|}{ Tank Use Side Inlet Node Name } \\
\hline \multicolumn{3}{|l|}{ Tank Use Side Outlet Node Name } \\
\hline \multicolumn{2}{|l|}{ DX Coil Object Type } & Coil'WaterHeating:AirToWaterHeatPump \\
\hline \multicolumn{2}{|l|}{ DX Coil Name } & HFWHDXCoil \\
\hline Minimum Inlet Air Temperature for Compressor Operatior & C & 5 \\
\hline Compressor Location & & Zone \\
\hline \multicolumn{3}{|l|}{ Compressor Ambient Temperature Schedule Name } \\
\hline Fan Nhiert Tune & & Fan:ПnПff \\
\hline
\end{tabular}

Figure 6-10 EnergyPlus Object WaterHeater:HeatPump 


\begin{tabular}{|l|l|l|}
\hline Field & Units & Obj1 \\
\hline Name & & HRV HX \\
\hline Availability Schedule Name & & Always On Discrete 28 \\
\hline Nominal Supply Air Flow Rate & m3/s & 0.046 \\
\hline Sensible Effectiveness at 100\% Heating Air Flow & dimensionless & 0.84 \\
\hline Latent Effectiveness at 100\% Heating Air Flow & dimensionless & 0.7 \\
\hline Sensible Effectiveness at 75\% Heating Air Flow & dimensionless & 0.9 \\
\hline Latent Effectiveness at 75\% Heating Air Flow & dimensionless & 0.75 \\
\hline Sensible Effectiveness at 100\% Cooling Air Flow & dimensionless & 0.84 \\
\hline Latent Effectiveness at 100\% Cooling Air Flow & dimensionless & 0.7 \\
\hline Sensible Effectiveness at 75\% Cooling Air Flow & dimensionless & 0.9 \\
\hline Latent Effectiveness at 75\% Cooling Air Flow & dimensionless & 0.75 \\
\hline Supply Air Inlet Node Name & & HRV 0A. Inlet \\
\hline Supply Air Outlet Node Name & & HRV 0A Mixer Inlet \\
\hline Exhaust Air Inlet Node Name & & HRV Relief Air Outlet Node \\
\hline Exhaust Air Outlet Node Name & & HRV Exhaust Fan inlet Node \\
\hline Nominal Electric Power & W & 50 \\
\hline Supply Air Outlet Temperature Control & & No \\
\hline Heat Exchanger Type & & Plate \\
\hline Frost Control Type & & ExhaustOnly \\
\hline Threshold Temperature & C & 1.7 \\
\hline Initial Defrost Time Fraction & dimensionless & 0.083 \\
\hline Rate of Defrost Time Fraction Increase & $1 / \mathrm{K}$ & 0.012 \\
\hline Economizer Lockout & & Yes \\
\hline
\end{tabular}

Figure 6-11 EnergyPlus Object HeatExchanger:AirToAir:SensibleAndLatent

Case $A$ is identical to the Baseline Case with the exception of one added

HeatExchanger:AirToAir:SensibleAndLatent object which connects to the heat

recovery ventilator exhaust stream 


\begin{tabular}{|c|c|c|c|c|}
\hline Field & Units & Obi1 & Obj2 & \\
\hline Name & & HRV HX & HRV Hot HPWH HX & \\
\hline Availability Schedule Name & & Always On & Always $0 n$ & \\
\hline Nominal Supply Air Flow Rate & $\mathrm{m} 3 / \mathrm{s}$ & 0.046 & 0.2685 & \\
\hline Sensible Effectiveness at $100 \%$ Heating Air Flow & dimensionless & 0.84 & 0.84 & \\
\hline Latent Effectiveness at $100 \%$ Heating Air Flow & dimensionless & 0.7 & 0.7 & \\
\hline Sensible Effectiveness at $75 \%$ Heating Air Flow & dimensionless & 0.9 & 0.9 & \\
\hline Latent Effectiveness at $75 \%$ Heating Air Flow & dimensionless & 0.75 & 0.75 & \\
\hline Sensible Effectiveness at $100 \%$ Cooling Air Flow & dimensionless & 0.84 & 0.84 & \\
\hline Latent Effectiveness at $100 \%$ Cooling Air Flow & dimensionless & 0.7 & 0.7 & \\
\hline Sensible Effectiveness at $75 \%$ Cooling Air Flow & dimensionless & 0.9 & 0.9 & \\
\hline Latent Effectiveness at 75\% Cooling Air Flow & dimensionless & 0.75 & $0.75 \cdots \cdots$ & - \\
\hline Supply Air Inlet Node Name & & HRV OA, Inlet & West Workspace Inlet & \\
\hline Supply Air Outlet Node Name & & HRV OA Mixer Inlet & West Workspace Outlet & \\
\hline Exhaust Air Inlet Node Name & & HRV Relief Air Outlet Node & HRV Exhaust Outlet & \\
\hline Exhaust Air Outlet Node Name & & HRV Exhaust Fan inlet Node & Final Exhaust Port & \\
\hline Nominal Electric Power & W & 50 & 50 & \\
\hline Supply Air Outlet Temperature Control & & No & No & \\
\hline Heat Exchanger Type & & Plate & Plate & \\
\hline Frost Control Type & & Exhaust0nly & Exhaust0nly & \\
\hline Threshold Temperature & C & 1.7 & 1.7 & \\
\hline Initial Defrost Time Fraction & dimensionless & 0.083 & 0.083 & \\
\hline
\end{tabular}

Figure 6-12 EnergyPlus objects HeatExchanger:AirToAir:SensibleAndLatent for Case A

Case $B$ is also identical to the Baseline with the exception of an added

\section{heat exchanger object that connects to the heat pump flow stream and one}

additional node added to the NodeList objects which facilitates the connection

\section{to the room air}

\begin{tabular}{|c|c|c|c|}
\hline Field & Units & Obi1 & $0 \mathrm{bj} 2$ \\
\hline Name & & HRV HX & HPWH Cool HRV HX \\
\hline Availability Schedule Name & & Always 0n & Always $0 n$ \\
\hline Nominal Supply Air Flow Rate & $\mathrm{m} 3 / \mathrm{s}$ & 0.046 & 0.046 \\
\hline Sensible Effectiveness at $100 \%$ Heating Air Flow & dimensionless & 0.84 & 0.84 \\
\hline Latent Effectiveness at $100 \%$ Heating Air Flow & dimensionless & 0.7 & 0.7 \\
\hline Sensible Effectiveness at $75 \%$ Heating Air Flow & dimensionless & 0.9 & 0.9 \\
\hline Latent Effectiveness at $75 \%$ Heating Air Flow & dimensionless & 0.75 & 0.75 \\
\hline Sensible Effectiveness at 100\% Cooling Air Flow & dimensionless & 0.84 & 0.84 \\
\hline Latent Effectiveness at $100 \%$ Cooling Air Flow & dimensionless & 0.7 & 0.7 \\
\hline Sensible Effectiveness at $75 \%$ Cooling Air Flow & dimensionless & 0.9 & 0.9 \\
\hline Latent Effectiveness at $75 \%$ Cooling Air Flow & dimensionless & 0.75 & 0.75 \\
\hline Supply Air Inlet Node Name & & HRV OA Inlet & HPWH HX inlet \\
\hline Supply Air Outlet Node Name & & HRV OA Mixer Inlet & PTHP Indoor Air Intake \\
\hline Exhaust Air Inlet Node Name & & HRV Relief Air Outlet Node & West Workspace Inlet \\
\hline Exhaust Air Outlet Node Name & & HRV Exhaust Fan inlet Node & West Workspace Outlet \\
\hline Nominal Electric Power & W & 50 & 50 \\
\hline Supply Air Outlet Temperature Control & & No & No \\
\hline Heat Exchanger Type & & Plate & Plate \\
\hline Frost Control Type & & Exhaust0nly & Exhaust Inly \\
\hline Threshold Temperature & C & 1.7 & 1.7 \\
\hline Initial Defrost Time Fraction & dimensionless & 0.083 & 0.083 \\
\hline
\end{tabular}

Figure 6-13 EnergyPlus objects HeatExchanger:AirToAir:SensibleAndLatent for Case B 


\begin{tabular}{|l|l|l|l|}
\hline Field & Units & Obj1 & Obj2 \\
\hline Name & & Port List 1 & Port List 2 \\
\hline Node 1 Name & & PTHP Conditioned Air Outlet & PTHP Indoor Air Intake \\
\hline Node 2Name & HRV Supply Fan Outlet & HRV Relief Air Outlet Node \\
\hline Node 3Name & & HFWH HX inlet \\
\hline Nande A Mame & & & \\
\hline
\end{tabular}

Figure 6-14 EnergyPlus objects NodeList for Case B 


\section{Appendix B - Additional Data Figures}

Figures 7-1 and 7-2 show the fan energy savings for Implementing Case A and Case B in Fairbanks and Phoenix respectively. In both climates a very small benefit or penalty is seen for Case A. A larger difference is seen for Case A.

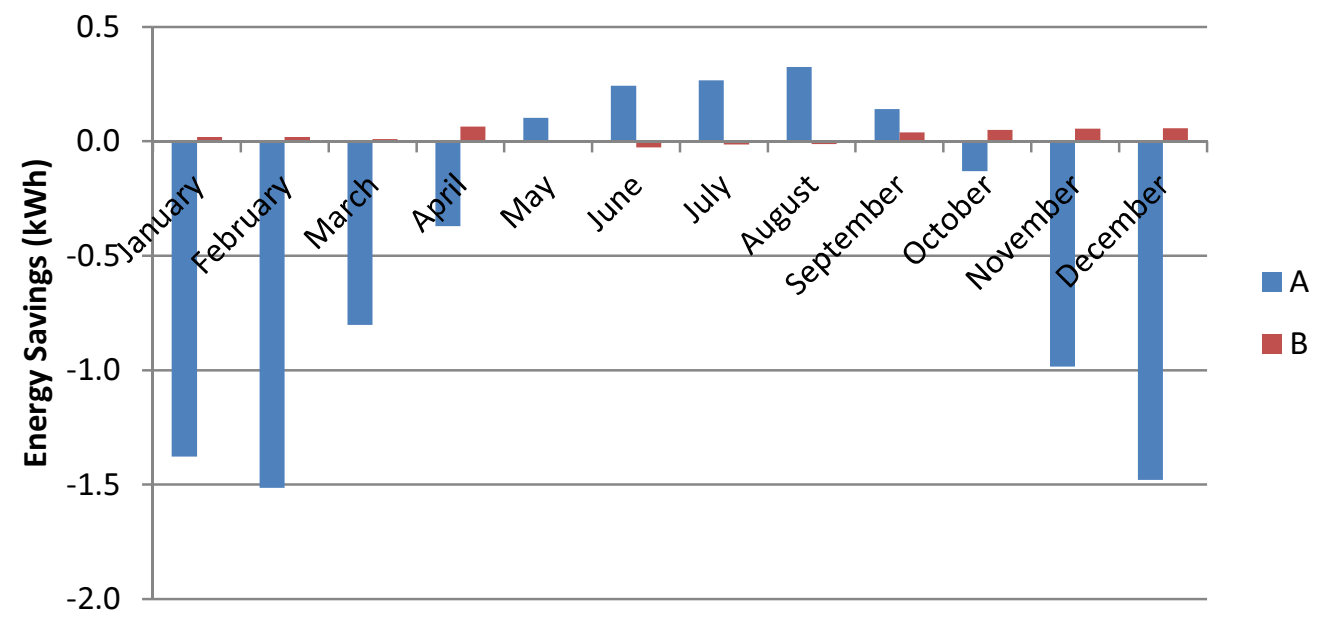

Figure 7-1 Fan Energy savings from Baseline Case for Fairbanks Alaska

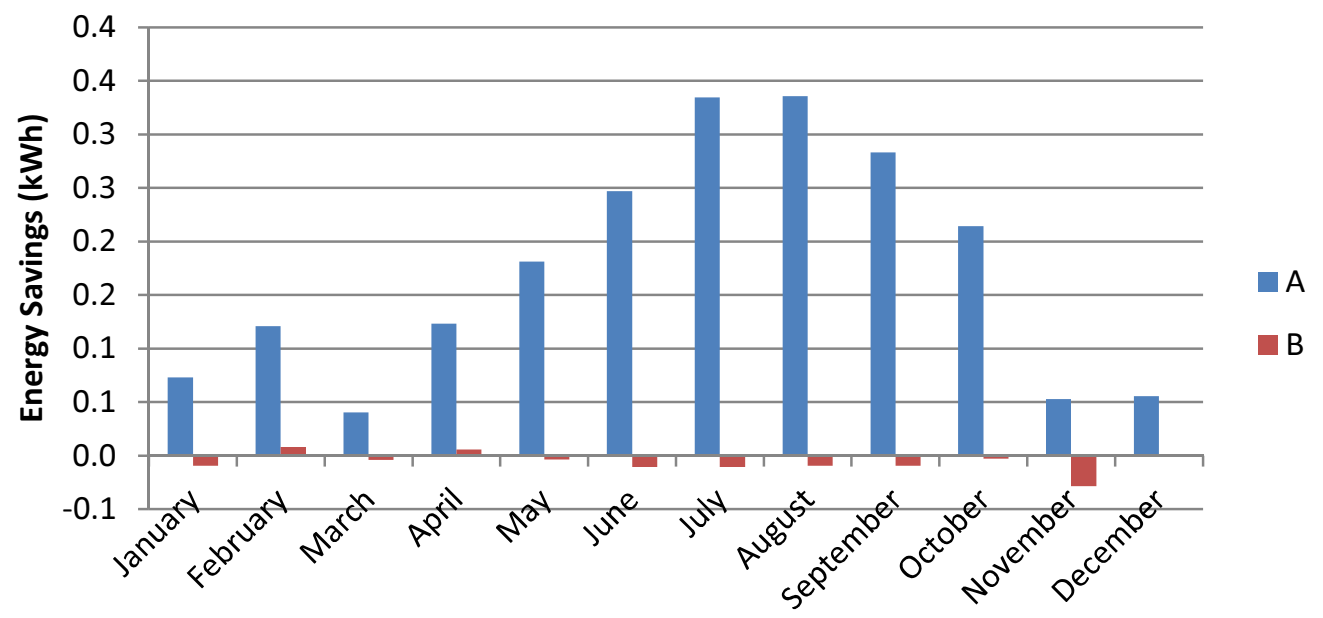

Figure 7-2 Fan Energy savings from Baseline Case for Phoenix Arizona 
Cooling energy savings from implementing Case A and Case B in Phoenix and Fairbanks are shown in Figures 7-3 and 7-4 respectively. A negligible savings is seen in case B for both climates, while Case A shows a visible but small penalty.

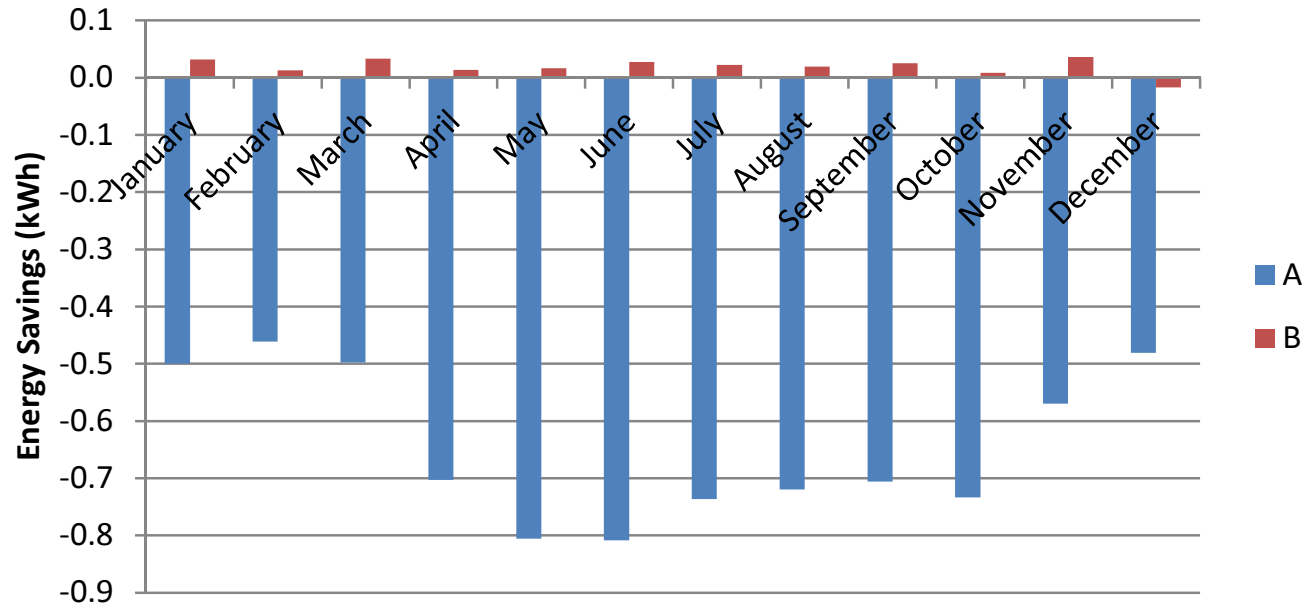

Figure 7-3 Cooling energy savings for Phoenix Arizona

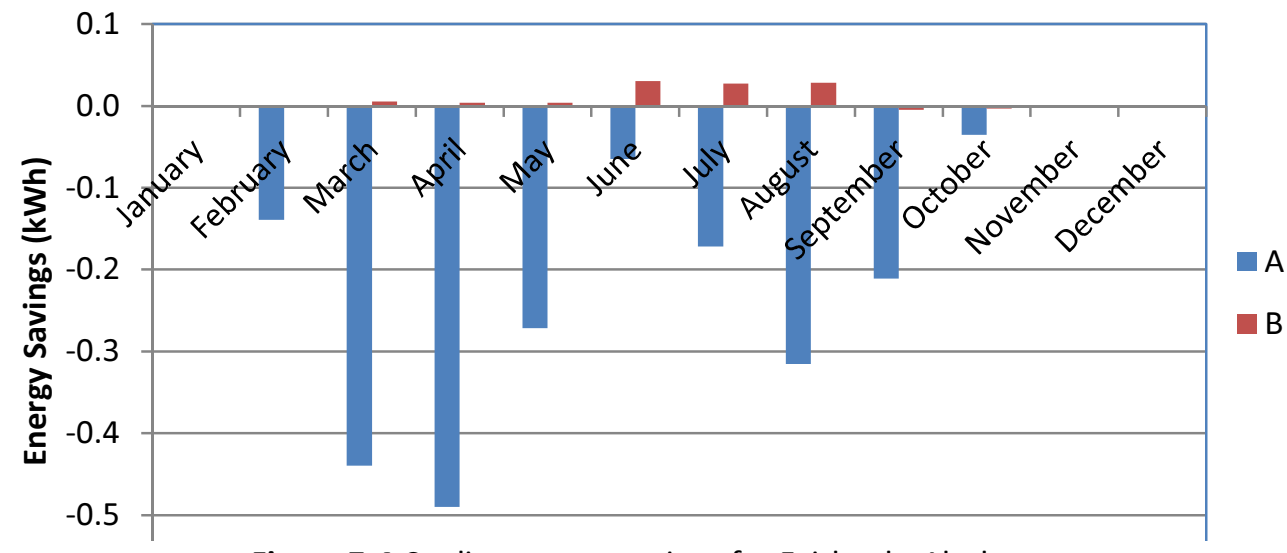

Figure 7-4 Cooling energy savings for Fairbanks Alaska 
There is a substantial heat recovery savings for Case B, while Case A

shows no benefit or penalty for heat recovery. Figure 7-5 shows that the Phoenix house only benefits on the non summer months. Figure7-6 shows that the greates benefit to the Fairbanks house is during the summer months. Case B causes a small penalty in domestic hot water energy for both Phoenix (Figure 77) and Fairbanks (Figure 7-8). Case A shows a substantial benefit to domestic hot water energy for both Phoenix and Fairbanks.

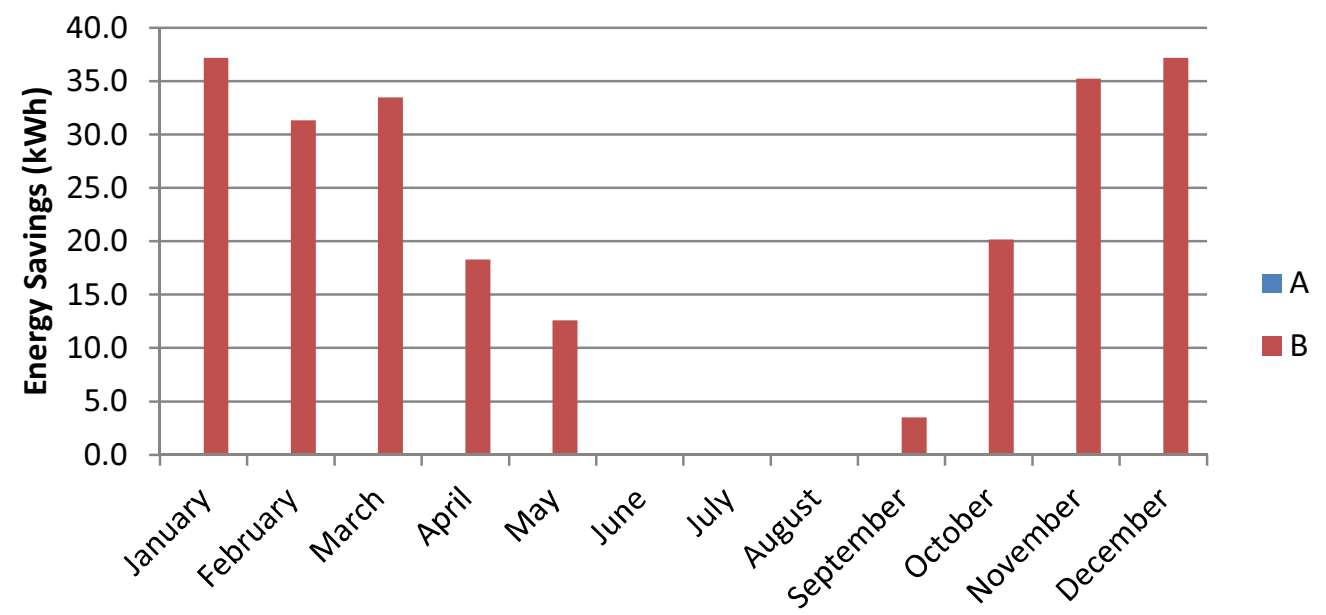

Figure 7-5 Heat recovery energy savings for Phoenix Arizona

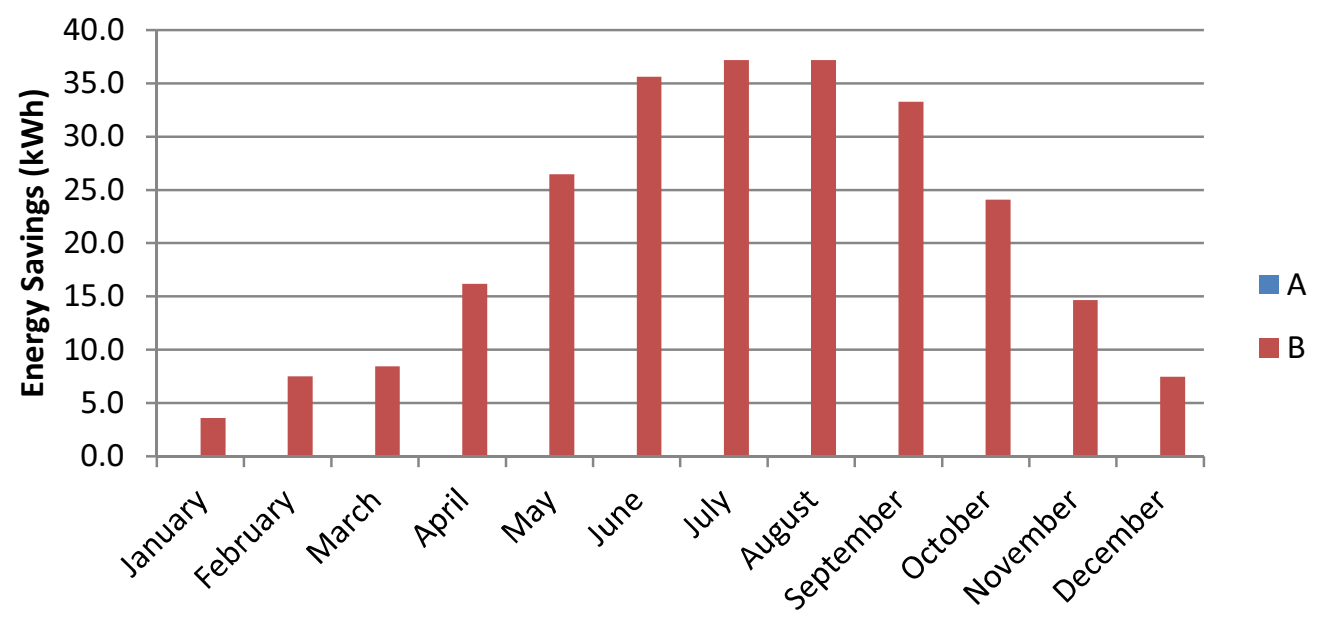

Figure 7-6 Heat recovery energy savings for Fairbanks Alaska 


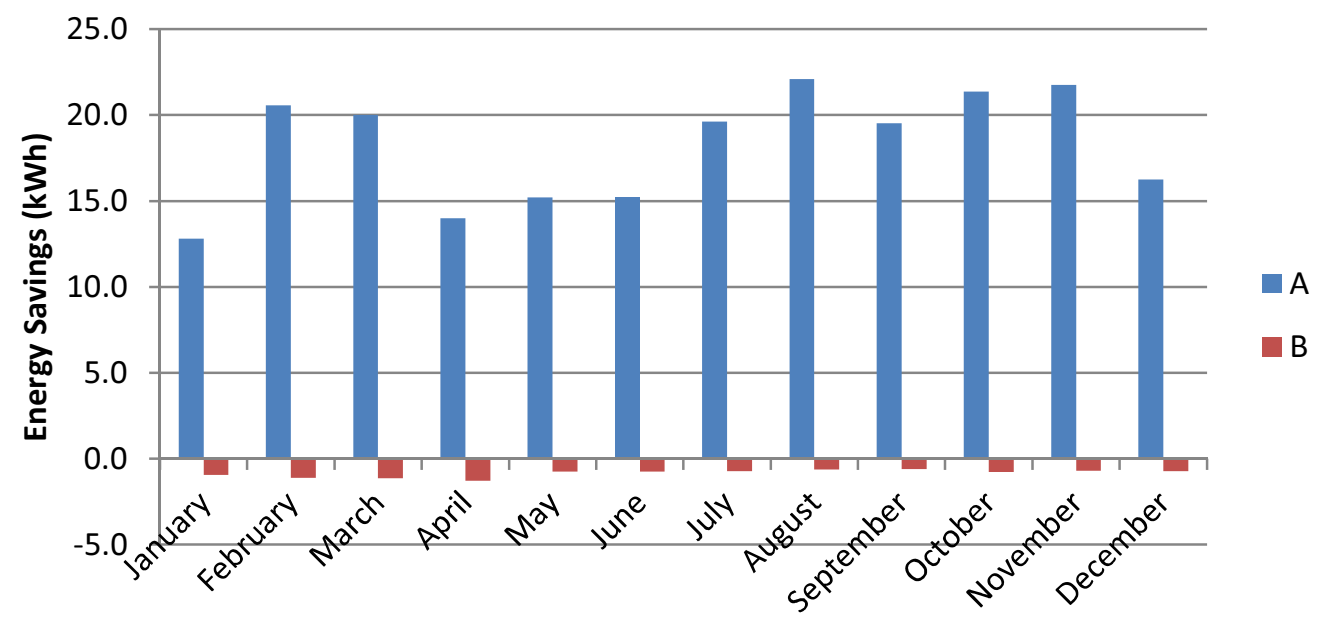

Figure 7-7 Domestic hot water energy savings for Phoenix Arizona

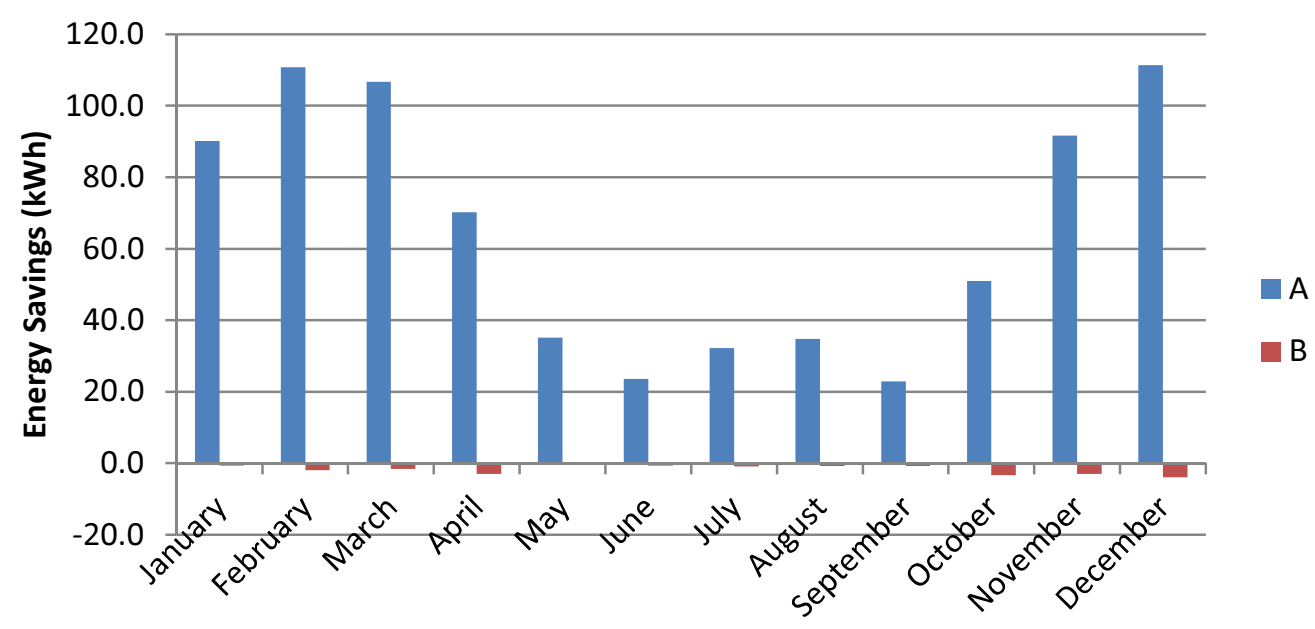

Figure 7-8 Domestic hot water energy savings for Fairbanks Alaska 
In Figure 7-9 Case B shows savings compared to the baseline case during all but the hottest times of day in Portland which indicates that bypass node is active.

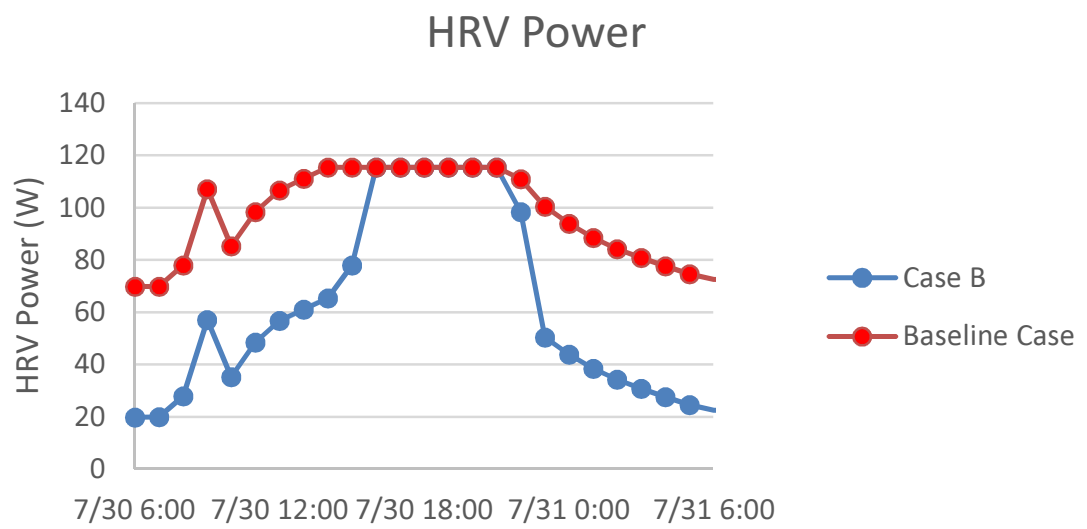

Figure 7-9 HRV power consumption during a hot day in Portland 


\section{Appendix C - Contents of Supplemental Data Files}

Simulation code can be run by opening and executing the input design files in EnergyPlus version 8.1. IDF and EPW are both file types unique to Energy Plus.

IDFs contain the inputs for building simulation while EPWs contain a weather file.

The IDF must be used concurrently with an EPW for simulations.

Folder Name: EnergyPlus IDFs

\begin{tabular}{|l|l|l|l|l|}
\hline File Name & $\begin{array}{l}\text { File } \\
\text { Type }\end{array}$ & $\begin{array}{l}\text { File Size } \\
\text { (KB) }\end{array}$ & Software & $\begin{array}{l}\text { Special } \\
\text { hardware } \\
\text { requirements }\end{array}$ \\
\hline Passive house simple & IDF & 218 & $\begin{array}{l}\text { Energy Plus } \\
8.1\end{array}$ & None \\
\hline Passive house simple B & IDF & 220 & $\begin{array}{l}\text { Energy Plus } \\
8.1\end{array}$ & None \\
\hline Passive house simple A & IDF & 220 & $\begin{array}{l}\text { Energy Plus } \\
8.1\end{array}$ & None \\
\hline $\begin{array}{l}\text { USA_AK_Emmonak.702084 } \\
\text { TMY3 }\end{array}$ & EPW & 1586 & $\begin{array}{l}\text { Energy Plus } \\
8.1\end{array}$ & None \\
\hline $\begin{array}{l}\text { USA_AZ_Phoenix- } \\
\text { Sky.Harbor.IntI.AP.722780_ } \\
\text { TMY3 }\end{array}$ & EPW & 1605 & $\begin{array}{l}\text { Energy Plus } \\
8.1\end{array}$ & None \\
\hline $\begin{array}{l}\text { USA_OR_Portland.Intl.AP.7 } \\
\text { 26980_TMY3 }\end{array}$ & EPW & 1605 & $\begin{array}{l}\text { Energy Plus } \\
8.1\end{array}$ & None \\
\hline
\end{tabular}

